The Impacts of Materialism on the Academic Behavior of Students due to Parental

\title{
Overseas Employment
}

\author{
Rei Joshua R. Amante \\ Rashela C. Ballesteros \\ John Kenneth S. Lopez \\ Yiana Maristela L. Mislang \\ Ashley Nicole M. Rosario \\ Junalyn C. Seguin
}

Virgen Milagrosa University Foundation Special Science High School

Bobby B. Dela Cruz, LPT, MEd

Practical Research 1

July 5, 2020 
Acknowledgment

This piece of Research becomes a reality with the generous help and support of many individuals. We would like to extend our sincere thanks to all of them.

Foremost, we want to offer this endeavor to our God Almighty for the wisdom he bestowed upon us, the strength, peace of our mind and good health in order to finish this research.

We would like to express our gratitude towards our beloved family, supportive friends, and loved ones, for the encouragement, immeasurable assistance, and support, which helped us in completion of this paper.

We would also like to express our gratitude and special thanks to Mr. Bobby B. Dela Cruz, LPT, MEd, our research adviser, for his constructive suggestions and guidance, and for giving us inspiration and challenge by making this research meaningful.

Our grammar teacher, Mr. Erwin DG. Manzon for sharing his knowledge and helping us in our choices of words.

To our respondents for their honest participation and cooperation response to all the questions solicited in this study.

Our thanks and appreciation also go the people in our school who have willingly helped us out with their abilities. 


\section{Dedication}

This piece of work is humbly dedicated to our dear families, friends, and loved ones for their immeasurable support. They are the persons who always believe, inspire, and guide us in all the things that we are doing. A special feeling of gratitude to all of them. We also dedicate this work to our appreciated research adviser, whose expertise and knowledge were generously shared, for his genuine apprehension, encouragement, patience, and guidance to make this research meaningful.

Above all, to our Almighty God, our creator - the source of our lives and our provider, for His immeasurable and ever-present love for all of us through Jesus Christ. All glory must be unto Him. We love you! 


\begin{abstract}
Students left behind by their overseas employed parents has become a common phenomenon in the Philippines. Most parents practice materialism to compensate for their absence. However, materialism may result to prevalent impacts on the students' academic behavior. The study used phenomenological design to determine the influences of materialism on the Grade 9 students' academic behavior enrolled at Virgen Milagrosa University Foundation Special Science High School. The sample population was obtained by non-probability quota sampling whereby only 20 students who have overseas employed parents and have been affected by materialism were the participants. The study used a profile form and an unstructured interview as tools for data collection. The data gathered were analyzed to answer the study's research questions. The major findings of the study showed that materialism positively affects the students' academic behavior primarily because of the advantages, rewards, and parental inspiration. Materialism also negatively affects the students' academic behavior mainly by causing distractions, wrong priorities, and poor conducts. Additional results relevant to the study were the different insights of the students about parental materialism and the leading materials they receive. The study concluded that materialism influences the students' academic behavior both positively and negatively based on different conditions. It was recommended that the findings of this study would be useful to the relative persons in understanding their situation broadly and in making solutions to resist the stated dilemma.
\end{abstract}

Keywords: overseas employed parents, materialism, pros and cons, students, academic behavior, school, education 


\section{Table of Contents}

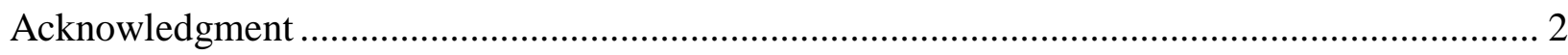

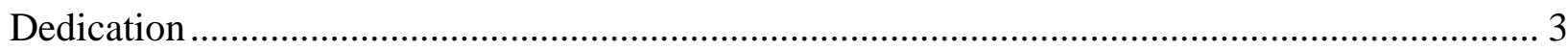

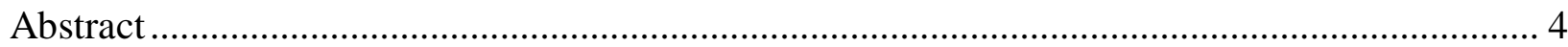

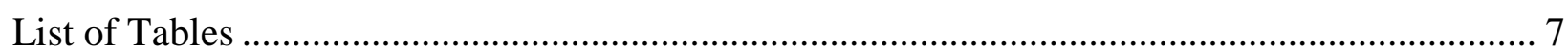

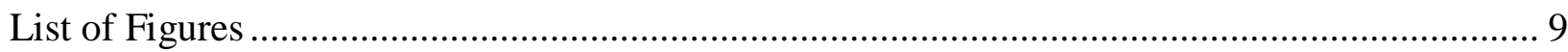

The Impacts of Materialism on the Academic Behavior of Students due to Parental

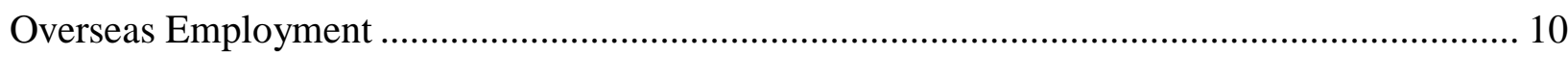

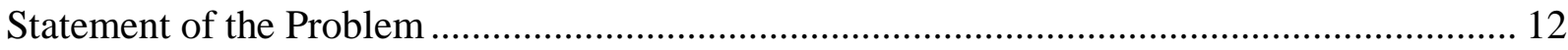

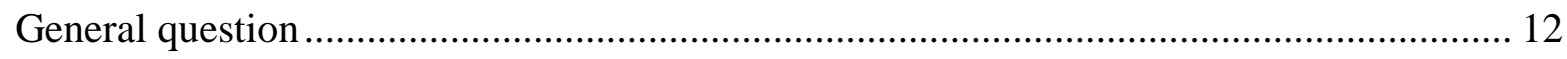

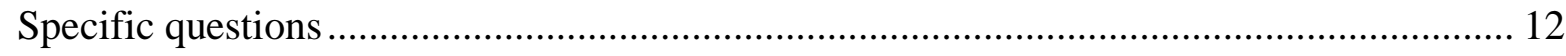

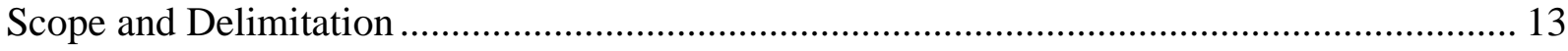

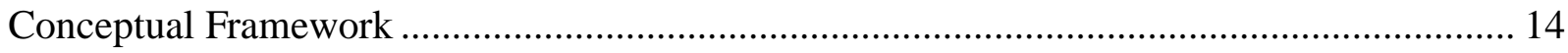

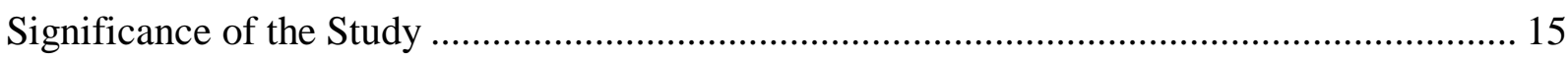

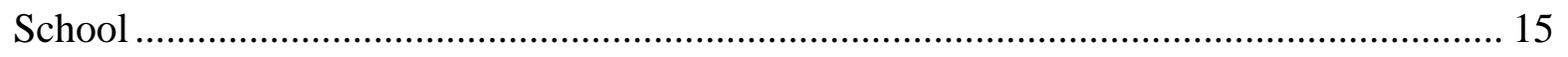

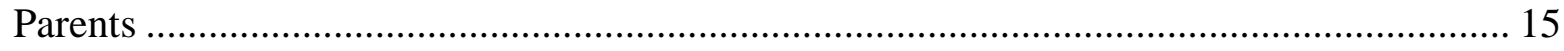

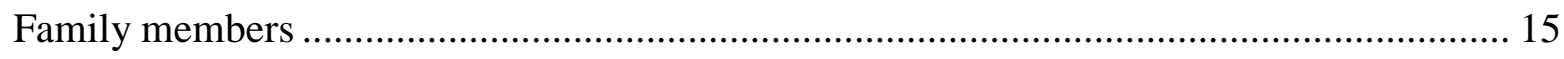

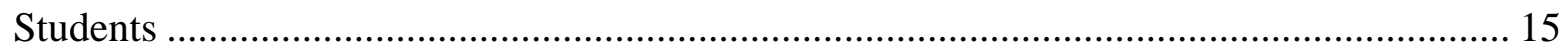

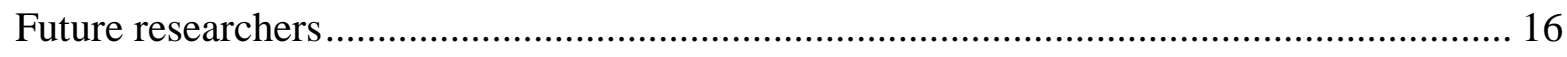

Review of Related Literature and Studies .................................................................. 17

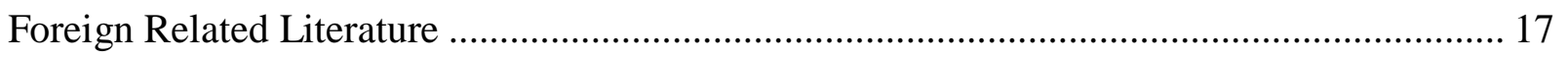




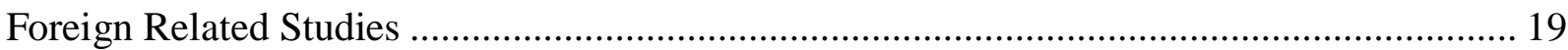

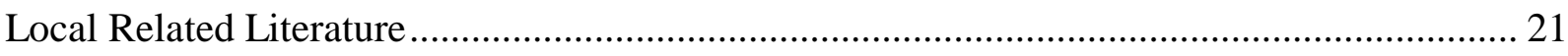

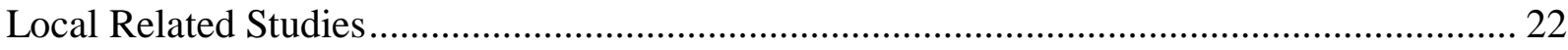

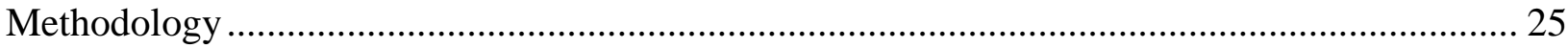

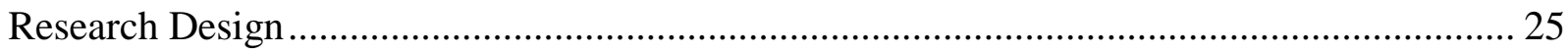

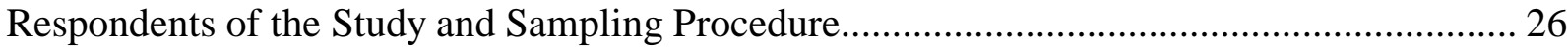

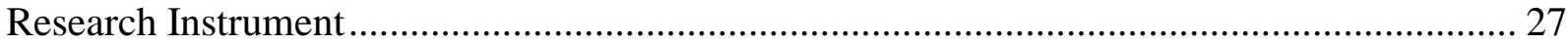

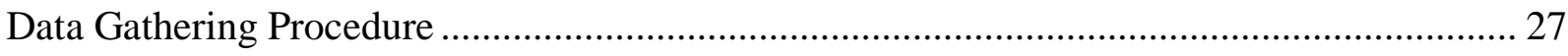

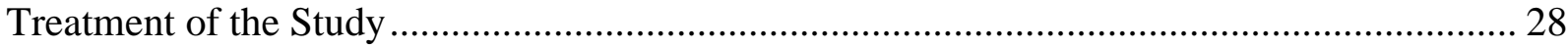

Presentation, Analysis, and Interpretation of Findings ................................................... 30

Summary, Findings, Conclusions, and Recommendations............................................. 86

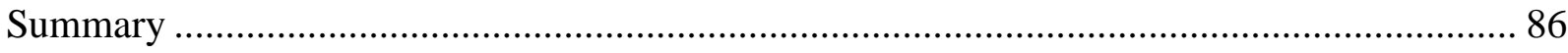

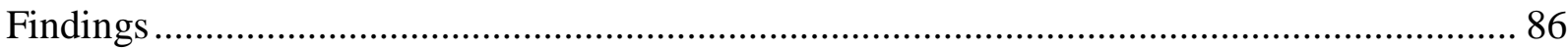

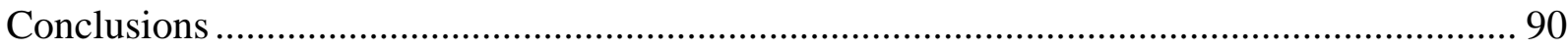

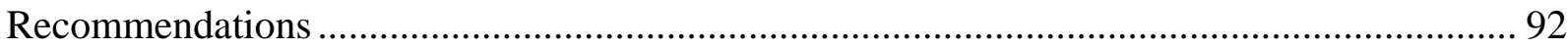

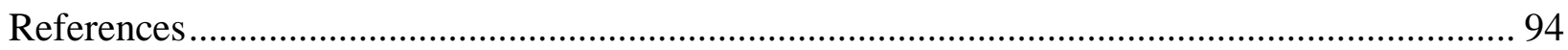

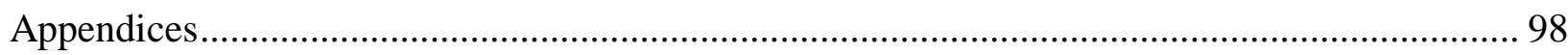

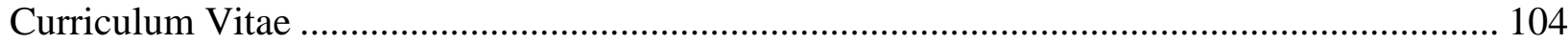




\section{List of Tables}

Table 1 Profile of the Respondents in terms of Gender .................................................... 30

Table 2 Profile of the Respondents in terms of Age ......................................................... 30

Table 3 Profile of the Respondents in terms of the Duration of Their Overseas Employed

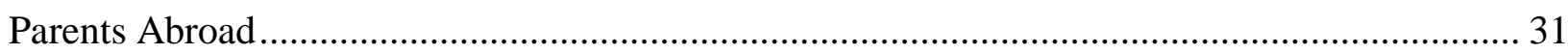

Table 4 Phase 1: Perceptions of the Students on the Concept of Parental Materialism ............ 32

Table 4.1 Phase 2: Tallying of Perceptions of the Students on the Concept of Parental

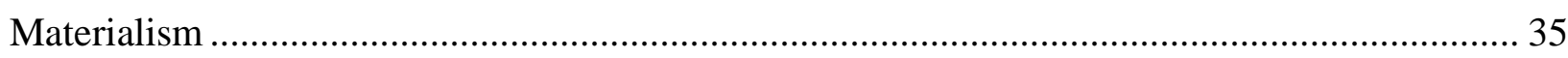

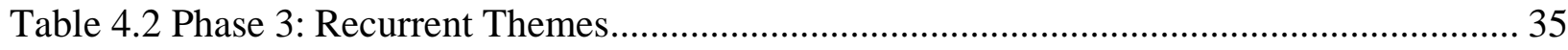

Table 5 Phase 1: Leading Materials Received by the Students ............................................ 37

Table 5.1 Phase 2: Tallying of Leading Materials Received by the Students .......................... 39

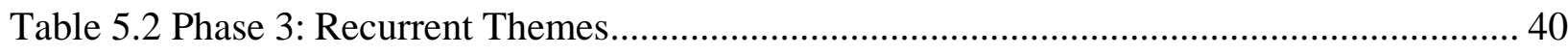

Table 6 Phase 1: Materialism as Compensation for Parental Absence................................. 41

Table 6.1 Phase 2: Tallying of Materialism as Compensation for Parental Absence................. 43

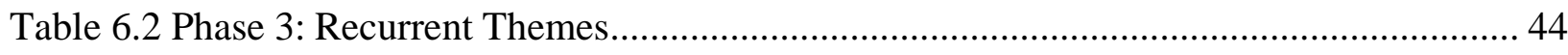

Table 7 Phase 1: Positive Impacts of Materialism on Grades ............................................ 45

Table 7.1 Phase 2: Tallying of Positive Impacts of Materialism on Grades............................. 47

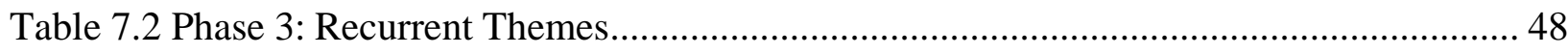

Table 8 Phase 1: Positive Impacts of Materialism on Educational Resources ....................... 49

Table 8.1 Phase 2: Tallying of Positive Impacts of Materialism on Educational Resources ....... 51

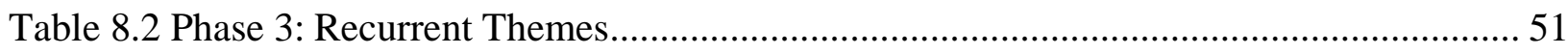

Table 9 Phase 1: Positive Impacts of Materialism on Self-esteem ..................................... 52

Table 9.1 Phase 2: Tallying of Positive Impacts of Materialism on Self-esteem...................... 55 


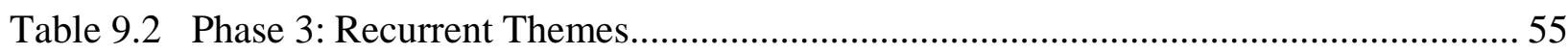

Table 10 Phase 1: Positive Impacts of Materialism on Motivation in Learning ………........... 57

Table 10.1 Phase 2: Tallying of Positive Impacts of Materialism on Motivation in

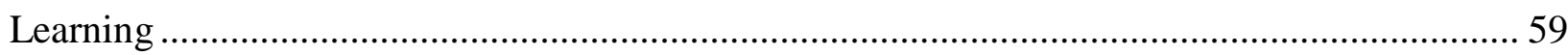

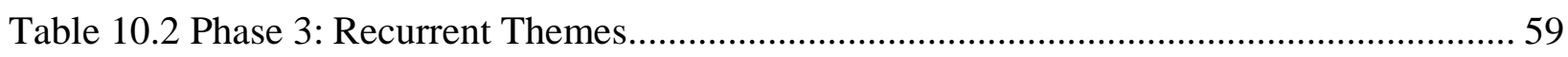

Table 11 Phase 1: Positive Impacts of Materialism on Class Participation.................................. 61

Table 11.1 Phase 2: Tallying of Positive Impacts of Materialism on Class Participation............. 63

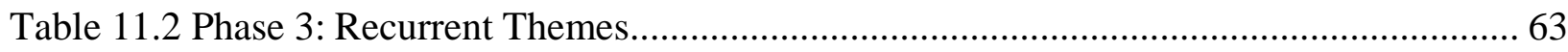

Table 12 Phase 1: Negative Impacts of Materialism on Grades ................................................. 64

Table 12.1 Phase 2: Tallying of Negative Impacts of Materialism on Grades ............................... 66

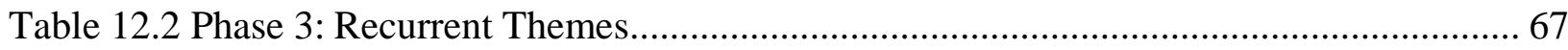

Table 13 Phase 1: Negative Impacts of Materialism on Educational Resources......................... 68

Table 13.1 Phase 2: Tallying of Negative Impacts of Materialism on Educational

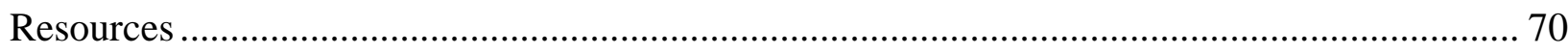

Table 13.2 Phase 3: Recurrent Themes.................................................................................. 70

Table 14 Phase 1: Negative Impacts of Materialism on Self-esteem ......................................... 72

Table 14.1 Phase 2: Tallying of Negative Impacts of Materialism on Self-esteem ...................... 74

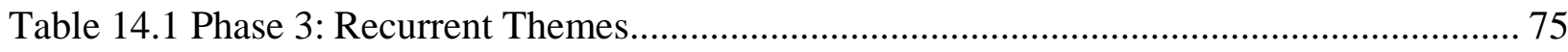

Table 15 Phase 1: Negative Impacts of Materialism on Motivation in Learning ....................... 77

Table 15.1 Phase 2: Tallying of Negative Impacts of Materialism on Motivation in

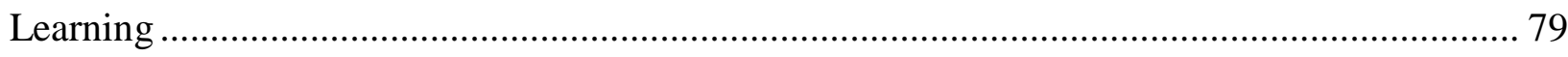

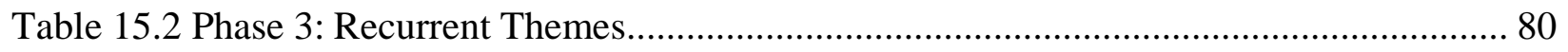


Table 16 Phase 1: Negative Impacts of Materialism on Class Participation ............................... 81

Table 16.1 Phase 2: Tallying of Negative Impacts of Materialism on Class Participation ........... 83

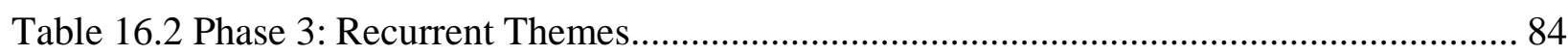

\section{List of Figures}

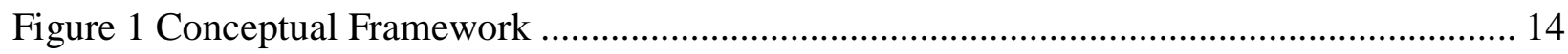


The Impacts of Materialism on the Academic Behavior of Students due to Parental Overseas Employment

Philippines is one of the countries that have the greatest number of Overseas Workers in the world. Overseas employment of parents may have positive or negative impacts on their family. Parents want to give their children an easy life. They migrate to other country just to earn high income for their designated job so that they can give their children the basic needs they have to acquire. In connection to this, we cannot escape the fact that working abroad means high probability of getting a lot of provisions because their income is much higher and most of the things are inexpensive in other country. One of the main reasons for overseas employment is the aim for having a financially stable life that would often lead to materialism on their children as a way to compensate parental absence. This will eventually have observable impacts to their children's academic behavior.

The parents are aware of their parental absence which in return, results to materialism. They can use this for a good purpose but sometimes, the students may be used to this and may live their life in materialism which subsequently results to negativities. Materialism is taking a constant concern over material possessions and wealth or a great or excessive regard for worldly concerns, and this is one of the effects of being employed overseas.

Mostly, parents compensate their absence by practicing materialism (Bernardo et al., 2018) to their children. Children who have an OFW Parent may have positive or 
negative impacts on their academic behaviors (Arguillas \& Williams, 2010) based on some circumstances and one of these is materialism. This part may lead to some students having lack of discipline or poor academic behavior. On the other hand, having a lot of materialistic belongings may motivate the students to engage in their study, if they are guided well. Children may be more motivated to learn, knowing that parents have gone abroad to work in order to provide them additional material and educational resources. But in contrast, this can also result to materialistic expectations to the parents rather than parental affection and will also afterward lead to adverse behaviors (Botezat \& Pfeiffer, 2014).

Materialistic students may lead to poor academic behavior. They might be distracted by their own materialistic possessions and their worldly life. Conversely, some students may understand this as their parents' motivation for them to study well, thus, encouraging them to perform good academic behavior. The students may think that they should be studying well to also pay off for their parents' hard work and sacrifices for them. This will affect the emotional and mental aspect of the students which may also have significant effects on their study. As a result of the increasing numbers of overseas Filipino employed parents, the dilemma on the academic behaviors of the students also continues to prevail.

Given this kind of situation, the researchers opted to conduct a study investigating the impacts of materialism on the academic behavior of students due to parental overseas employment in Virgen Milagrosa University Foundation Special Science High School to 
raise awareness not only to the overseas Filipino employed parents and students but also to the community.

\section{Statement of the Problem}

This study was conducted to find out the impacts of materialism on the academic behavior of Grade 9 students due to parental overseas employment in Virgen Milagrosa University Foundation Special Science High School in San Carlos City, Pangasinan during the school year 2019-2020.

It answered the following questions:

General question. What are the influences of materialism on the academic behavior of students who have overseas employed parents?

\section{Specific questions.}

1. What are the profiles of the respondents in terms of
a. Grades
b. Age
c. Duration of their overseas employed parents abroad?

2. How do the Grade 9 students perceive the concept of parental materialism?

3. What are the three leading materials received by the Grade 9 students from their overseas employed parents?

4. How does materialism compensate for the absence of the Grade 9 students' overseas employed parents? 
5. What are the positive impacts of materialism on the academic behaviors of Grade 9 students with regards to their
a. Grades
b. Educational resources
c. Self-esteem
d. Motivation in learning
e. Class participation?

6. What are the negative impacts of materialism on the academic behaviors of Grade 9 students with regards to their
a. Grades
b. Educational resources
c. Self-esteem
d. Motivation in learning
e. Class participation?

\section{Scope and Delimitation}

This phenomenological study aimed to determine the impacts of materialism on the academic behavior of students due to parental overseas employment among the Grade 9 high school students in Virgen Milagrosa University Foundation Special Science High School in San Carlos City, Pangasinan. The study used non-probability sampling method and participants were asked through unstructured interview. The researchers limited this study to only assess the 20 Grade 9 students enrolled during the school year 2019-2020 
who have overseas employed parents and have been affected by materialism to discern the positive and negative impacts of materialism on their academic behavior.

\section{Conceptual Framework}

The researchers conceptualized and constructed Figure 1 to represent the relationship among the variables used in the study. It included the input, process, and output of the study.

\section{Figure 1}

Conceptual Framework
Input

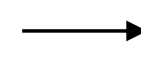
Process
Output

Grade 9 students
Virgen Milagrosa
University Foundation
Special Science High
School
Overseas employed
parents
Materialism
Academic behavior of
the students

\begin{tabular}{|c|}
\hline $\begin{array}{c}\text { Non-probability } \\
\text { sampling } \\
\text { Quota sampling } \\
\text { method }\end{array}$ \\
Phenomenological \\
study \\
Profile form and \\
unstructured interview \\
Frequencies and \\
percentage \\
Thematic analysis
\end{tabular}

\begin{tabular}{|c|}
\hline \\
The impacts of \\
materialism on the \\
academic behavior of \\
students due to \\
parental overseas \\
employment \\
\end{tabular}

The paradigm showed the relationship between the respondents, other inputs and the data gathering processes in order to find the outputs, which were the impacts of materialism on the academic behavior of students due to parental overseas employment. 


\section{Significance of the Study}

This study has significance to several areas and numerous benefactors. Generally, the results of this study are advantageous to bring awareness to the school, overseas employed parents, other family members, and students about the academic behavioral impacts of materialism. The outcomes of the study were significant to the different sectors, which are as follows:

School. It can provide deeper knowledge on what strategies they can use to educate or counsel the students about the conditions of having overseas employed parents. It can also give the teachers another perspective on why the children would act a certain way.

Parents. This study may push the parents to give more parental attention and guidance to their children, as well as giving enough but not abounding financial or material assistance.

Family members. This study may help other family members to decide to be the bridge for the overseas employed parents and the students, for better understanding and monitoring of their current condition.

Students. The study can help the students to be open-minded and matured thinkers. The results and findings of this study could provide the students more knowledge and understanding about the effects of having materialism, their current situation, and their responsibility to consequently help them to demeanor good discipline. It can also give the student a different point of views or realization towards the topic. Moreover, the findings of this study may similarly provide a useful tool for realizing, by 
helping the students understand that having an OFW parent should not be a hindrance to their education.

Future researchers. The findings of this study can be additional references for the future researchers regarding on this topic. The ideas presented in this research may be used as reference data conducting new researches or in testing the validity of other related findings. 


\section{Review of Related Literature and Studies}

This section presented the literatures and studies relevant to the concept of this study. It analyzed the studies and materials to provide sufficient background and information essential for this study.

\section{Foreign Related Literature}

A study by (Lu, 2014) asserted that the outmigration of parents has become a common childhood experience worldwide. It can confer both economic benefits and social costs on children. The study also examined how the relationship between parental out-migration and children's education. The results showed that children left behind by international migrant parents are worse off in educational attainment than those living with both parents.

According to one study conducted by (Richins \& Chaplin, 2015), parents use material goods every day in their interactions with children. Other than providing their children with basic needs, parents may also give them things or goods like toys, electronic devices, clothes, and other materialistic possessions. Often, these discretionary items have a practical purpose. Sometimes, parents do this to show their love to their children. They want their children to be happy. Also, parents use material things to shape their children's behavior. For example, parents may give reward to their children because of their accomplishments or parents may take things as a consequence of disobedience or neglect of responsibilities. 
These researches imply that students can acquire good academic behavior for being financially stable by sending them into a preferably exclusive school to have the best education. Observed studies show how later level of materialism is associated with psychological need's satisfaction (Wang et al., 2016), and coping with loneliness (Elodie et al., 2018).

In contrasting opinion, a study by (Tian \& Lu, 2015) stated that people with high materialism play a negative role in which their life would normally show low life satisfaction and excessively chasing the material world. In addition to this, (Datu, 2017) articulated that students high in materialism have poorer engagement and achievement, and these associations are partially mediated by lower motivation. The pursuit of extrinsic goals may thwart the fulfilment of one's basic psychological needs there leading to poorer outcomes.

Nevertheless, a research study by (Moshahid \& Vadakkayil, 2016) claimed that an academically favorable home environment is likely to enhance the child's motivation to achieve academic success which in turn will contribute to good performance in school. Similarly, (Tian \& Lu, 2015) revealed one theory on positive emotions from Fredrickson's the broaden-and-build theory of positive emotions, which suggests that positive emotions can not only expand the scope of people's awareness, but also help to build people's individual resources. Additionally, the study outlines that when people foster the positive emotions, they cannot only be counterbalanced to the hostile fondness 
which the materialism brings, but also have a new understanding of the life satisfaction and change the preference to make decisions.

These researches suggest that regardless of the parents' work, income, or financial assistance, they should not repudiate their responsibility on their children's emotional aspect whether they are far or not physically in touched with their children. The researches also pertain to the migration of the parents to gain money and to give the things that their children want or need. The parents give things to their children to overcome their lack of parental attention. The parents should also focus on the emotional aspect of their children, not merely on the materialistic ones, to provoke good discipline within the children. They need more positivity in their lives for them to attain health connection with each other, so as fostering good behavior or discipline of the students.

\section{Foreign Related Studies}

A study by (Botezat \& Pfeiffer, 2014) explained that migration of parents abroad for working purposes may be an important way of generating income and reducing unemployment in the sending countries. Migration may have also positive and/or negative consequences for children left at home. On the one hand parents often get better paid jobs abroad, providing their children with more financial and educational resources and fostering social and school achievement. On the other hand, however, missing the main adult caregiver may be harmful for children's well-being. Children may be more motivated to learn, knowing that parents have gone abroad to work in order to provide them additional material and educational resources. But in contrast, this can also result to 
materialistic expectations to the parent(s) rather than parental affection and will also afterward lead to adverse behaviors.

In the same way, (Mutie, 2015) claimed parents believe that the best way to compensate their parental absence is to reward excessive material necessities to their children. This has changed many children's perception or understanding that their parents are nothing but just material providers. Due to this, the mutual cohesiveness that is supposed to exist between parents and children may have been also greatly eroded. It also assumes that when parents superfluously provide their children with material things, the discipline of children may erode.

An article about how materialism can hinder maturity in students by (Elmore, 2013) presented that today's teenagers are being more materialistic and the reason for this is likely the fault of adults who created a culture that breeds materialism. It has been also said that teens who experience materialism tend to be lazy and less willing to work hard for their selves instead of being motivated. As a result, parents may feel that they are compelled to get those stuffs for their children. This indicates a poor relationship between the students and the parents and would often lead to falsely behavior. Another commentary by (Kohli, 2015) stressed the effects of material parenting in which parents use material goods to express their love or to shape the behavior or their children. Their children tend to be more responsible to earn the things they want through good behavior.

To sum it all up, different researchers formulated that being materialistic can be a way of motivation to their children to study well or a way of shaping their children's 
behavior. It correspondingly summarizes both positive and negative impacts of materialism.

\section{Local Related Literature}

Based on the results from (Philippine Statistics Authority, 2019) survey on overseas Filipino workers on 2018, it was estimated that approximately 2.3 million people of Filipino descents lived or worked abroad or Overseas Filipino Workers (OFWs). In behalf of this, the Department of Foreign Affairs (DFA) is the prime agency of government responsible for the pursuit of the state's foreign policy. It has been also said that the economic benefits of OFWs are emphasized on the Chapter II-Section 6 of R.A. 10801 or the OWWA Act. It is the Act Governing the Operations and Administration of the Overseas Workers Welfare Administration. But, with this continuing huge number of Filipino migrants, a more pressing concern is about the children left behind.

A research on the topic by (Arguillas \& Williams, 2010) exposed the possible circumstances of overseas employments of parents to their children. It has been said that overseas migration of parents from the Philippines has resulted in increasing numbers of long-term separations of parents from each other and from their children. Western-based analyses might predict negative education outcomes for children as a result of parental absence. We find the effects of separations caused by overseas migration are often neutral or can have positive effects on schooling outcomes. 
A research by (Bernardo et al., 2018) explained that children left behind by parents who are overseas Filipino workers (OFW) benefit from parental migration because their financial status improves. However, OFW families might emphasize the economic benefits to compensate for their separation, which might lead to materialism among children left behind. Previous research indicates that materialism is associated with lower well-being. Moreover, materialism focuses attention on comparing one's possessions to others, making one constantly dissatisfied and wanting more.

\section{Local Related Studies}

Overseas Filipino Workers are occurring in conformity here in the Philippines. These individuals work overseas because of the perks of having higher salary and several opportunities given in other countries than staying in the Philippines. These people work strenuously, and they endure the pain in order to sustain the needs of their families which are the food, clothing, rent, medical fund, education, recreation fund and extra money for emergency purposes. The main and utmost reason why the parents decided to work abroad is to send their children to a preferably school and to sustain their needs in everyday life. Thus, this motivated the students to study hard and pursue their studies. If the students pursue their studies, they can make their parents proud and when that happens their parents will support them more and this would lead to further betterment of students' academic performance. (Alegria et al., 2018)

A study conducted by (Iso, 2017) stated that most Filipino migrant parents think that the closeness of their relationship cannot be measured by physical relation, but it is 
how parents do their role to make their children' lives good. The migrations of the parents have a lot of effects to those children left behind. It affects the child emotional aspect, social aspect and the perception in life of the child. These children are vulnerable to lots of problem and also becoming self-doubting because of the lack of attention from parents. Additionally, it explained that children who left behind are more likely to be materialistic. It has been said that most of the OFW children have become so materialistic and spend their parent's money on gadgets and internet gaming from lack of guidance. The remittance is being wasted on self-absorption.

A piece of writing by (Espiritu, 2015) also asserted that materialism has psychological effects, such as low self-esteem, and vulnerability to peer pressure. Many young people have a strong desire to fit in with their peers. They believe that one way to do so is to have the same things that others have. And if they don't, they fear being ousted or left alone, youths with low self-esteem are more likely to be more materialistic. They use things to make themselves happy. Materialism may also affect the brain development of young people. Once a young person becomes used to getting what he wants, he tends to want more and more, instead of appreciating what he has. He doesn't think about the consequences, such as arrested development from focusing on unnecessary things instead of developing his brain, finding out who he is and learning what he can give to the world.

In recompense to this, a research by (Atienza et al, 2012) explained that it is emotionally and physically challenging for the children to accept that their family set-up 
is not the same with other families. However, as the child begins to understand the rationale why the parent has to work abroad and is able to get back on track and take on the responsibility of managing their own. In addition, In the Philippines, having a bluecollared job, one would not be able to financially support their families unlike when they work abroad.

Researchers revealed that parental overseas employment can effectuate materialism especially on their children, thus it can affect the behavior of the students negatively or positively through various circumstances. These reviewed literatures contributed facts and results from previous studies that will help in the strong justification of the present study, focusing on the impacts of materialism on the academic behavior of students due to parental overseas employment. 


\section{Methodology}

The methods and procedures of the study was presented in this section. It showed the research design, respondents of the study, sampling and sampling technique, data gathering procedure, instruments of the study, and the treatment of the data.

\section{Research Design}

For this research study about the impacts of materialism on the academic behavior of students due to parental overseas employment, the researchers used phenomenology research design.

According to the evaluated study of (De Mey, 2013), design is a word which means a plan or something that is conceptualized by the mind whereas research design serves as a blueprint or a skeletal framework of the research study. Phenomenology research is used to recognize the ways of how people undergo unavoidable happenings in their life to get a clue or pattern of their techniques in coming to terms with the positive or negative results of their life experience stated in the study of (Baraceros, 2016).

The design sought to know the certain impacts of materialism on the academic behavior of the Grade 9 students due to parental overseas employment in Virgen Milagrosa Special Science High School. The researchers gathered the data from the Grade 9 students who have this experience to know the circumstances in their lives. It enabled the researchers to explore experiences and perception of the research phenomenon, and the realization of understanding based on the experiences and perceptions of the students. 


\section{Respondents of the Study and Sampling Procedure}

In this study that investigated the impacts of materialism on the academic behavior of students due to parental overseas employment, the researchers' target population were the Grade 9 students enrolled at Virgen Milagrosa University

Foundation Special Science High School for the school year 2019-2020, who have overseas employed parents and have been affected by materialism. The source population were the 50 Grade 9 students who have overseas employed parents, whereas the samples were the 20 Grade 9 students who have overseas employed parents and have been affected with materialism.

Non-probability sampling was used to gather the sample data needed by the researchers. As defined by (Baraceros, 2016), sampling refers to the method or process of selecting respondents or people to answer questions meant to yield data for a research study. Non-probability sampling or biased sampling is a sampling method where in the subjects are selected based on the purpose of the study.

The type of non-probability sampling used was quota sampling where the researchers pursued to identify participants who could correspond to the strict objectives and criteria of the study. Quota sampling method was also used in this study to get the agreeable representative and number of respondents. Foley (2018), defined that quota sampling technique is a type of non-probability sampling in which researchers look for a specific characteristic in their respondents, and then take a tailored sample that is in proportion to a population of interest. 
From the entire population of 126 Grade 9 students, 5 students who have overseas employed parents were chosen from each of the four (4) sections of Virgen Milagrosa University Foundation Special Science High School. Only 20 students were selected as the samples since they were the qualified subject of the study.

\section{Research Instrument}

For this study, a profile structure and an unstructured interview were given to the Grade 9 Students of Virgen Milagrosa University Foundation Special Science High School. In an unstructured sort of interview, the respondents answer the inquiries openly all alone and there are no proposed answers (Baraceros, 2016).

The meeting offered expected to survey the Grade 9 students who have abroad utilized guardians to assess the effects of realism on their scholastic conduct. It included open-finished inquiries to enable the understudies to yield the information about their circumstance and conduct.

Unstructured interviews do not use any set questions, instead, the interviewer asks open-ended questions based on a specific research topic, and will try to let the interview flow like a natural conversation. The interviewer modifies his or her questions to suit the candidate's specific experiences.

\section{Data Gathering Procedure}

In this study, the data was gathered through a profile form and an unstructured interview. The researchers carefully constructed the questions and asked approval from the research adviser, the principal, and other experts to conduct the interview. After the 
approval of the research adviser, the researchers started to formally conduct the study. The study was thoroughly explained to the respondents. Their permission was first asked through a consent letter and the researchers published only the data they would want to appear. The interview questions were administered online to the respondents to assess their specific behaviors, views or opinions toward materialism brought by their overseas employed parents.

Considering ethical aspect of research, this research was accomplished with appropriate guidelines. Enough time was given to the respondents of the study so that they could depict their views on research questions. Consent from the respondents were taken and appropriate permission were also ensured for usage of their given data. The disclosure of the respondents' identities was based on their permission. Hence, the ethical aspect of research is followed very strictly in this study.

\section{Treatment of the Study}

The overall data of the Grade 9 students who have overseas employed parents were gathered from the interview and were treated in utmost confidentiality. In analyzing and comparing the data or the frequency that were collected from the study, the responses that identified the Grade 9 students' behavior, understanding, situations, and experiences towards materialism due to overseas employment were collected, tallied, and presented.

This qualitative research study concentrated on non-statistical measurement of data. However, the profiles of the respondents were presented in tables to show the frequencies and percentages. The presentation of data was focused on analyzing and 
interpreting the gathered subjective data. The positive and negative impacts of materialism on the academic behavior of the Grade 9 students who have overseas employed parents that came the answers, opinions and results from the study were shown in tabularized and narrative form. 


\section{Presentation, Analysis, and Interpretation of Findings}

This section encompassed the presentation, analysis, and interpretation of collected data about the impacts of materialism on the academic behavior of students due to parental overseas employment. It further decoded the most imperative knowledge and understandings necessary for drawing conclusions and recommendations. Findings were presented in tables and sequence of simplified specific interpretations for an easy and better understanding of the results.

\section{Table 1}

Profile of the Respondents in terms of Gender

\begin{tabular}{lll}
\hline Gender & Frequency & Percentage $(\%)$ \\
\hline Male & 9 & $45 \%$ \\
Female & 11 & $55 \%$ \\
\hline Total & 20 & $100 \%$ \\
\hline
\end{tabular}

Table 1 presented that in majority, 11(55\%) of the respondents were females while $9(45 \%)$ were males. According to (Mutie, 2015) females are more responsive on opening to matters regarding their private lives than males; hence it appeared that more females opted to partake in this research than males.

\section{Table 2}

Profile of the Respondents in terms of Age

\begin{tabular}{lll}
\hline Age & Frequency & Percentage $(\%)$ \\
\hline 14 & 8 & $40 \%$ \\
15 & 12 & $60 \%$ \\
\hline Total & 20 & $100 \%$ \\
\hline
\end{tabular}


Table 2 showed the ages of Grade 9 students of Virgen Milagrosa University Foundation Special Science High School who participated in this study. In majority, $12(60 \%)$ of the respondents were aged 15 years while $8(40 \%)$ were aged 14 years. The Discussion Paper on the Enhanced K+12 Basic Education Program by the (Department of Education of the Philippines, 2010), presented K-6-4-2 Model Implementation which states that the onset standard age for Grade 9 students is at 14 years old, therefore supporting the age bracket 14 to 15 years old.

\section{Table 3}

Profile of the Respondents in terms of the Duration of Their Overseas Employed Parents Abroad

\begin{tabular}{lll}
\hline Age & Frequency & Percentage $(\%)$ \\
\hline 11 Months and Below & 6 & $30 \%$ \\
$1-2$ Years & 4 & $20 \%$ \\
3-4 Years & 2 & $10 \%$ \\
5-6 Years & 0 & $0 \%$ \\
7 Years and Above & 8 & $40 \%$ \\
\hline Total & 20 & $100 \%$ \\
\hline
\end{tabular}

Table 3 showed that in majority, $8(40 \%)$ of the respondents had their parents working abroad for 7 years or above, followed by 6(30\%) for 11 months and below, next was $4(20 \%)$ for $1-2$ years and $2(10 \%)$ for $3-4$ years, while $0(0 \%)$ or no respondents had their parents working for 5-6 years abroad. Thus, the students who had longer-term OFW parents were in majority. A research on the topic by (Arguillas \& Williams, 2010) has 
explained that overseas migration of parents from the Philippines has resulted in increasing numbers of long-term separations from their children.

\section{Table 4}

Phase 1: Perceptions of the Students on the Concept of Parental Materialism

\begin{tabular}{|c|c|c|c|}
\hline \multicolumn{4}{|c|}{ Question 1: What can you say about parental materialism? } \\
\hline $\begin{array}{l}\text { Key- } \\
\text { respondents }\end{array}$ & Retrieved Data & Preliminary Codes & Codes \\
\hline Par 1 & $\begin{array}{l}\text { Parental materialism can greatly help } \\
\text { the children in acquiring their needs. }\end{array}$ & Sustenance & Stn \\
\hline Par 2 & $\begin{array}{l}\text { Being materialistic could produce } \\
\text { issues that parents and children may } \\
\text { not agree with. Sometimes } \\
\text { materialistic attitude among parents } \\
\text { could impede harmonious relationship } \\
\text { for both. For example, I requested } \\
\text { something I really want, but they } \\
\text { couldn't give it to me. It would hurt } \\
\text { my feeling and it could lead us to } \\
\text { sulk. }\end{array}$ & Relational & $\mathrm{R} \ln$ \\
\hline Par 3 & $\begin{array}{l}\text { It can affect one's growth and } \\
\text { development because of being used to } \\
\text { materialism, positively and } \\
\text { negatively. }\end{array}$ & Equitable Impacts & EIm \\
\hline Par 4 & $\begin{array}{l}\text { It's how OFW parents show their kids } \\
\text { that they care and still think of them } \\
\text { and their needs when they're abroad. }\end{array}$ & Concern & $\mathrm{Cnc}$ \\
\hline Par 5 & $\begin{array}{l}\text { It affects me because we are not } \\
\text { living together in the same house. If I } \\
\text { have problems, I do not know whom I } \\
\text { should talk to- they're not here to } \\
\text { personally give me advices, but I do } \\
\text { understand why they chose to work } \\
\text { overseas. }\end{array}$ & Relational & $\mathrm{R} \ln$ \\
\hline Par 6 & $\begin{array}{l}\text { It is okay to give materialistic } \\
\text { provisions, but it needs limitations. } \\
\text { Parents should not always give what }\end{array}$ & All Right & $\mathrm{ARg}$ \\
\hline
\end{tabular}




\begin{tabular}{|c|c|c|c|}
\hline & $\begin{array}{l}\text { their children ask. Also, children } \\
\text { should not always request materials to } \\
\text { their parents. The children might } \\
\text { become used to it. }\end{array}$ & Restraint & Rst \\
\hline Par 7 & $\begin{array}{l}\text { For me, parental materialism is the } \\
\text { basis of the parent's capability to give } \\
\text { the needs of their children. }\end{array}$ & Sustenance & Stn \\
\hline Par 8 & $\begin{array}{l}\text { It both helps positively \& negatively } \\
\text { to my life. }\end{array}$ & Equitable Impacts & EIm \\
\hline Par 9 & $\begin{array}{l}\text { For me, it is okay because my parent } \\
\text { provides me what I need and what I } \\
\text { want. }\end{array}$ & Sustenance & Stn \\
\hline Par 10 & $\begin{array}{l}\text { It shouldn't be too much. Parents } \\
\text { should not also neglect giving } \\
\text { attention to their children such as } \\
\text { talking to them like video calls. }\end{array}$ & Restrain & Rst \\
\hline Par 11 & $\begin{array}{l}\text { I think parental materialism should } \\
\text { also be limited. Parents should not } \\
\text { just give all their children's wants; } \\
\text { they shouldn't spoil their kids. }\end{array}$ & Restrain & Rst \\
\hline \multirow[b]{2}{*}{ Par 12} & \multirow{2}{*}{$\begin{array}{l}\text { Parental materialism is most common } \\
\text { in those families, where the parents } \\
\text { do not spend a lot of time with their } \\
\text { children. Materialism in those } \\
\text { families is inevitable because parents } \\
\text { will always give what their children } \\
\text { want in order to make up for their } \\
\text { lack of time in bonding with their } \\
\text { children. I do not approve of the ways } \\
\text { some parents to deal with the lack of } \\
\text { time to bond with their children. They } \\
\text { will always end up spoiling the child } \\
\text { because they keep on giving the } \\
\text { wants of their child thinking that they } \\
\text { have made up for their absence. }\end{array}$} & Spoil & Spl \\
\hline & & Compensation & Cps \\
\hline
\end{tabular}




\begin{tabular}{|c|c|c|c|}
\hline Par 13 & $\begin{array}{l}\text { Children like us should not be } \\
\text { dependable on our parent's } \\
\text { materialistic provisions. Rather, we } \\
\text { should always be thankful for their } \\
\text { love for us. }\end{array}$ & Restraint & Rst \\
\hline Par 14 & $\begin{array}{l}\text { Parental materialism is about } \\
\text { something that the parents of an } \\
\text { individual must go abroad for the } \\
\text { needs of their daughter or son. So, it } \\
\text { is hard for me, as an individual, to see } \\
\text { my father go away from my side. }\end{array}$ & Equitable Impacts & EIm \\
\hline Par 15 & $\begin{array}{l}\text { It brings positive and negative impact } \\
\text { to the behavior of the child. }\end{array}$ & Equitable Impacts & EIm \\
\hline Par 16 & $\begin{array}{l}\text { Because of the too much love of the } \\
\text { parents for their children, sometimes } \\
\text { they become unmindful that they just } \\
\text { always give what their kids want. }\end{array}$ & Spoil & Spl \\
\hline Par 17 & $\begin{array}{l}\text { Parental materialism is the OFW } \\
\text { parents' coping mechanism when } \\
\text { they're physically absent from their } \\
\text { children. It is how they show their } \\
\text { love even if they are in other country. }\end{array}$ & Concern & Cnc \\
\hline Par 18 & $\begin{array}{l}\text { It is okay as long as we know our } \\
\text { limitations because it has pros and } \\
\text { cons. }\end{array}$ & Equitable Impacts & EIm \\
\hline Par 19 & $\begin{array}{l}\text { I think parental materialism is a fair } \\
\text { thing. It is how the parents show that } \\
\text { the reason they chose to work abroad } \\
\text { is to provide their children's needs. }\end{array}$ & Sustenance & Stn \\
\hline \multirow{2}{*}{ Par 20} & \multirow{2}{*}{$\begin{array}{l}\text { Parental materialism is just fine } \\
\text { unless it becomes too much. It should } \\
\text { be balanced. }\end{array}$} & All Right & $\mathrm{ARg}$ \\
\hline & & Balance & $\mathrm{Bln}$ \\
\hline
\end{tabular}




\section{Table 4. 1}

Phase 2: Tallying of Perceptions of the Students on the Concept of Parental Materialism

\begin{tabular}{|c|c|}
\hline Perception of the Students & N \\
\hline Stn & 4 \\
\hline ARg & 2 \\
\hline Cnc & 2 \\
\hline Cps & 1 \\
\hline EIm & 5 \\
\hline Rst & 4 \\
\hline Bln & 1 \\
\hline Spl & 2 \\
\hline Rln & 2 \\
\hline
\end{tabular}

Table 4. 2

Phase 3: Recurrent Themes

\begin{tabular}{|l|l|}
\hline \multicolumn{1}{|c|}{ Categories } & \multicolumn{1}{c|}{ Sub-categories } \\
\hline Perception of Satisfaction & $\begin{array}{l}\text { Sustenance (PS-Stn) } \\
\text { All Right (PS-ARg) }\end{array}$ \\
\hline Perception of Coping Mechanism & $\begin{array}{l}\text { Concern (PCM-Cnc) } \\
\text { Compensation (PCM-Cps) }\end{array}$ \\
\hline Perception of Neutral Perception & Equitable Impacts (PN-EIm) \\
\hline Perception of Limitation & $\begin{array}{l}\text { Restraint (PL-Rst) } \\
\text { Balance (PL-Bln) }\end{array}$ \\
\hline Perception of Disadvantage & $\begin{array}{l}\text { Spoil (PD-Spl) } \\
\text { Relational (PD-Rln) }\end{array}$ \\
\hline
\end{tabular}


The presented data showed that the key-participants were expressing five major different perceptions toward materialism. These themes were Satisfaction, Coping Mechanism, Neutral Perception, Limitation, and Disadvantage. In majority, the keyparticipants expressed their Satisfaction towards materialism; (5) responses on Sustenance and (2) responses on All Right. They said that materialism helped them in their everyday lives and they agreed with it. This was followed by neutral perception, which they stated that materialism could lead to both positive and negative effects on their lives; (5) responses on Equitable Impacts. Others claimed that it needs to be limited in some ways; (4) responses on Restraint and (1) response on Balanced. Some claimed that materialism is a disadvantage for them; (2) responses on Spoil and (2) also responses on Relational. Whereas few stated that parents use materialism as a coping mechanism; (2) responses on Concern and (1) response on Compensation. These results implied that the students' perception towards materialism varies.

One study of (Bernardo et al., 2018) has stated that children left behind by parents who are overseas Filipino workers (OFW) benefit from parental migration. While (Arguillas \& Williams, 2010) has claimed that children who have an OFW parent may have positive or negative impacts on them. Additionally, (Mutie, 2015) claims that when parents superfluously provide their children with material things, the discipline of children and the mutual cohesiveness that is supposed to exist between parents and children may greatly erode. Observed studies show how later level of materialism is associated with coping with loneliness (Elodie et al., 2018). Moreover, one study conducted by (Richins \& Chaplin, 2015) has explained that these discretionary items 
often have a practical purpose and sometimes, parents do this to show their love to their children.

\section{Table 5}

Phase 1: Leading Materials Received by the Students

Question 2: What are the three leading materials that you receive from your parents?

\begin{tabular}{|c|c|c|c|}
\hline $\begin{array}{c}\text { Key- } \\
\text { respondents }\end{array}$ & Retrieved Data & Preliminary Codes & Codes \\
\hline \multirow{4}{*}{ Par 1} & \multirow{4}{*}{ Cash, Food, Clothing/shoes } & Money & Mny \\
\hline & & Food & $\mathrm{Fd}$ \\
\hline & & Clothes & Cth \\
\hline & & Footwear & Ftw \\
\hline \multirow{3}{*}{$\operatorname{Par} 2$} & \multirow{3}{*}{ Shoes, Clothes, and Cash } & Footwear & Ftw \\
\hline & & Clothes & Cth \\
\hline & & Money & Mny \\
\hline \multirow{3}{*}{ Par 3} & \multirow{3}{*}{ Chocolate, Cell phone, Bag } & Chocolates & Chc \\
\hline & & Cellphone & $\mathrm{Cph}$ \\
\hline & & Bag & $\mathrm{Bg}$ \\
\hline \multirow{3}{*}{ Par 4} & \multirow{3}{*}{ Books, clothes, shoes } & Books & Bks \\
\hline & & Clothes & Cth \\
\hline & & Footwear & Ftw \\
\hline \multirow{3}{*}{ Par 5} & \multirow{3}{*}{$\begin{array}{l}\text { Everyday expenses, Laptop, School } \\
\text { supplies }\end{array}$} & Money & Mny \\
\hline & & Laptop & Ltp \\
\hline & & School Supplies & $\mathrm{SSp}$ \\
\hline \multirow{3}{*}{ Par 6} & \multirow{3}{*}{ Phone, BP light stick, AirPods } & Cellphone & Cph \\
\hline & & Light Stick & $\mathrm{LSt}$ \\
\hline & & Earphones & Eph \\
\hline \multirow{3}{*}{$\operatorname{Par} 7$} & \multirow{3}{*}{ Food, Clothes, Personal Needs } & Food & $\mathrm{Fd}$ \\
\hline & & Clothes & Cth \\
\hline & & Personal & Prs \\
\hline
\end{tabular}




\begin{tabular}{|c|c|c|c|}
\hline \multirow{3}{*}{ Par 8} & \multirow{3}{*}{ Gadgets, Musical Instruments, Books } & Gadgets & Gdg \\
\hline & & Musical Instrument & MIn \\
\hline & & Books & Bks \\
\hline \multirow{3}{*}{ Par 9} & \multirow{3}{*}{ Money, Clothes, Food } & Money & Mny \\
\hline & & Clothes & Cth \\
\hline & & Food & $\mathrm{Fd}$ \\
\hline \multirow{3}{*}{ Par 10} & \multirow{3}{*}{ Clothes, Money, Food } & Clothes & Cth \\
\hline & & Money & Mny \\
\hline & & Food & $\mathrm{Fd}$ \\
\hline \multirow{3}{*}{ Par 11} & \multirow{3}{*}{ Clothes, Bag, Shoes } & Clothes & Cth \\
\hline & & Bag & $\mathrm{Bg}$ \\
\hline & & Footwear & Ftw \\
\hline \multirow{3}{*}{ Par 12} & \multirow{3}{*}{ Clothes, Food, Expenses } & Clothes & Cth \\
\hline & & Food & $\mathrm{Fd}$ \\
\hline & & Money & Mny \\
\hline \multirow{3}{*}{ Par 13} & \multirow{3}{*}{$\begin{array}{l}\text { Cell phone, Bluetooth Earphones, } \\
\text { Laptop }\end{array}$} & Cell Phone & $\mathrm{Cph}$ \\
\hline & & Earphones & Eph \\
\hline & & Laptop & Ltp \\
\hline \multirow{3}{*}{ Par 14} & \multirow{3}{*}{ Gadgets, Wearable things, Money } & Gadgets & Gdg \\
\hline & & Wearables & Wrb \\
\hline & & Money & Mny \\
\hline \multirow{3}{*}{ Par 15} & \multirow{3}{*}{ Laptop, Drone, Chocolates } & Laptop & Ltp \\
\hline & & Drone & Drn \\
\hline & & Chocolates & Chc \\
\hline \multirow{3}{*}{ Par 16} & \multirow{3}{*}{ Gadgets, Clothes, Footwear } & Gadgets & Gdg \\
\hline & & Clothes & Cth \\
\hline & & Footwear & Ftw \\
\hline \multirow{3}{*}{ Par 17} & \multirow{3}{*}{$\begin{array}{l}\text { Cellphone, Portable Piano, Film } \\
\text { camera }\end{array}$} & Cellphone & Cph \\
\hline & & Musical Instruments & MIn \\
\hline & & Film Camera & $\mathrm{FCm}$ \\
\hline \multirow{3}{*}{ Par 18} & \multirow{3}{*}{ Laptop, Shoes, Cell Phone } & Laptop & Ltp \\
\hline & & Footwear & Ftw \\
\hline & & Cellphone & Cph \\
\hline
\end{tabular}




\begin{tabular}{|c|c|c|c|}
\hline \multirow{3}{*}{ Par 19} & \multirow{3}{*}{ Gadgets, Jewelries, Money } & Gadgets & Gdg \\
\hline & & Jewelries & Jwl \\
\hline & & Money & Mny \\
\hline \multirow{3}{*}{ Par 20} & \multirow{3}{*}{ Chocolates, Cash, Gifts } & Chocolates & Chc \\
\hline & & Money & Mny \\
\hline & & Gifts & Gft \\
\hline
\end{tabular}

\section{Table 5. 1}

Phase 2: Tallying of Leading Materials Received by the Students

\begin{tabular}{|c|c|}
\hline Leading Materials & $\mathrm{N}$ \\
\hline Mny & 9 \\
\hline $\mathrm{Fd}$ & 5 \\
\hline Cth & 9 \\
\hline Ftw & 6 \\
\hline Chc & 3 \\
\hline $\mathrm{Cph}$ & 5 \\
\hline $\mathrm{Bg}$ & 2 \\
\hline Bks & 2 \\
\hline Ltp & 4 \\
\hline $\mathrm{SSp}$ & 1 \\
\hline LSt & 1 \\
\hline Eph & 2 \\
\hline Prs & 1 \\
\hline Gdg & 4 \\
\hline MIn & 2 \\
\hline Wrb & 1 \\
\hline Drn & 1 \\
\hline $\mathrm{FCm}$ & 1 \\
\hline
\end{tabular}




\begin{tabular}{|l|c|}
\hline Jwl & 1 \\
\hline Gft & 1 \\
\hline
\end{tabular}

Table 5. 2

Phase 3: Recurrent Themes

\begin{tabular}{|c|c|}
\hline Categories & Sub-categories \\
\hline Apparel & $\begin{array}{l}\text { Clothes (A-Cth) } \\
\text { Footwear (A-Ftw) } \\
\text { Bag (A-Bg) } \\
\text { Jewelries (A-Jwl) }\end{array}$ \\
\hline Electronic Devices & $\begin{array}{l}\text { Cellphone (E-Cph) } \\
\text { Laptop (E-Ltp) } \\
\text { Earphones (E-Eph) } \\
\text { Gadgets (E-Gdg) } \\
\text { Drone (E-Drn) }\end{array}$ \\
\hline Financial Assistance & Money (FA-Mny) \\
\hline Food & $\begin{array}{l}\text { Food }(\mathrm{F}-\mathrm{Fd}) \\
\text { Chocolates }(\mathrm{F}-\mathrm{Chc})\end{array}$ \\
\hline Personal Things & $\begin{array}{l}\text { Personal (PT-Prs) } \\
\text { Musical Instruments (PT-MIn) } \\
\text { Film Camera (PT-FCm) } \\
\text { Gifts (PT-Gft) }\end{array}$ \\
\hline Educational Resources & $\begin{array}{l}\text { Books (ER-Bks) } \\
\text { School Supplies (ER-SSp) }\end{array}$ \\
\hline
\end{tabular}

Based on the presented data, there were six major materials received by the students from their parents. These were apparel, electronic devices, financial assistance, 
food, personal things, and educational resources. The first leading material that they receive was apparel with (9) responses on Clothes, (6) responses on Footwear, (2) responses on $\mathrm{Bag}$, and (1) response on Jewelries. The second leading material was electronic devices with a total of (16) responses on its sub-categories. The third leading material was financial assistance with (9) responses on Money. Some materials mentioned were food with (8) responses on its sub-categories, personal things with (4) responses on its sub-categories, and educational resources with (3) responses on its subcategories. This results implied that the students received various materialistic materials from their overseas employed parents.

Other than providing their children with basic needs, parents may also give them things or goods like toys, electronic devices, clothes, and other materialistic possessions (Richins \& Chaplin, 2015).

\section{Table 6}

Phase 1: Materialism as Compensation for Parental Absence

\begin{tabular}{|c|c|c|c|}
\hline \multicolumn{3}{|c|}{ Question 3: How does materialism compensate for your parent's absence? } \\
\hline $\begin{array}{c}\text { Key- } \\
\text { respondents }\end{array}$ & \multicolumn{1}{|c|}{ Retrieved Data } & Preliminary Codes & Codes \\
\hline Par 1 & $\begin{array}{l}\text { Even though they're far from me, it is } \\
\text { just fine because materialism helps me } \\
\text { in my life and studies. }\end{array}$ & Life & Lf \\
\cline { 2 - 4 } Par 2 & $\begin{array}{l}\text { It can express the love of my parents } \\
\text { through giving materials or rewards. }\end{array}$ & Education & Edc \\
\hline
\end{tabular}




\begin{tabular}{|c|c|c|c|}
\hline Par 3 & $\begin{array}{l}\text { Materialism cannot compensate for } \\
\text { my parent's absence. I still feel } \\
\text { different when they're around, but I } \\
\text { am grateful that they give me such } \\
\text { things. }\end{array}$ & Deny & Dny \\
\hline \multirow{2}{*}{ Par 4} & \multirow{2}{*}{$\begin{array}{l}\text { It shows that they still care about my } \\
\text { wellbeing and shows that in the place } \\
\text { of their absence are the products of } \\
\text { their hard work in abroad that will } \\
\text { help me while they're gone. }\end{array}$} & Care & $\mathrm{Cr}$ \\
\hline & & Provision & Prv \\
\hline \multirow{2}{*}{ Par 5} & \multirow{2}{*}{$\begin{array}{l}\text { It helps me in my studies and daily } \\
\text { Life. }\end{array}$} & Life & $\mathrm{Lf}$ \\
\hline & & Education & Edc \\
\hline Par 6 & It entertains me while they're not here. & Entertainment & Ent \\
\hline \multirow[b]{2}{*}{$\operatorname{Par} 7$} & \multirow{2}{*}{$\begin{array}{l}\text { It is their way to show that they still } \\
\text { care for me even though they are far. } \\
\text { Because of materialism, I can feel that } \\
\text { they are always with me and they } \\
\text { support me. }\end{array}$} & Care & $\mathrm{Cr}$ \\
\hline & & Provision & Prv \\
\hline Par 8 & $\begin{array}{l}\text { The games on my laptop entertain me, } \\
\text { so it's okay. }\end{array}$ & Entertainment & Ent \\
\hline Par 9 & $\begin{array}{l}\text { They give me material provisions so } \\
\text { that I can remember them though } \\
\text { they're not here. }\end{array}$ & Association & Asc \\
\hline Par 10 & $\begin{array}{l}\text { It draws my attention towards other } \\
\text { things in order to lessen my longing } \\
\text { for them. }\end{array}$ & Entertainment & Ent \\
\hline Par 11 & $\begin{array}{l}\text { For me, it doesn't compensate for my } \\
\text { parent's absence. The materials they } \\
\text { are giving are just like the things that } \\
\text { they can give me while they work here } \\
\text { but it is 'upgraded'. }\end{array}$ & Deny & Dny \\
\hline Par 12 & $\begin{array}{l}\text { They provide the needs and wants } \\
\text { completely. They have more } \\
\text { opportunities in working abroad than } \\
\text { here in the Philippines. }\end{array}$ & Provision & Prv \\
\hline
\end{tabular}




\begin{tabular}{|c|c|c|c|}
\hline Par 13 & $\begin{array}{l}\text { Because of what they give to me, I can } \\
\text { be more focused on my studies. It } \\
\text { becomes easier for me to answer my } \\
\text { homework. }\end{array}$ & Education & Edc \\
\hline Par 14 & $\begin{array}{l}\text { I am not with my father that's why I } \\
\text { become more independent and the } \\
\text { provisions make it easier. }\end{array}$ & Provision & Prv \\
\hline Par 15 & $\begin{array}{l}\text { Materialism helps us know that my } \\
\text { father still remembers us. }\end{array}$ & Association & Asc \\
\hline Par 16 & $\begin{array}{l}\text { It makes me happy. But the truth is, } \\
\text { materialism can never change the } \\
\text { feeling of being with your parents } \\
\text { every single day. Because you feel } \\
\text { secured and protected when they are } \\
\text { around. }\end{array}$ & Entertainment & Ent \\
\hline Par 17 & $\begin{array}{l}\text { It reminds the child of parental love } \\
\text { while they're absent. But in a good } \\
\text { way, they can provide the child's } \\
\text { needs. }\end{array}$ & Love & Lv \\
\hline Par 18 & $\begin{array}{l}\text { Material things don't really have value } \\
\text { for me. But if it is from my parents, it } \\
\text { means a lot to me. Through } \\
\text { materialism, I can see their hardships } \\
\text { in working. }\end{array}$ & Association & Asc \\
\hline Par 19 & $\begin{array}{l}\text { It represents the effort of my father } \\
\text { abroad to provide our needs and } \\
\text { wants. }\end{array}$ & Provision & Prv \\
\hline Par 20 & Materialism shows their love for me. & Love & Lv \\
\hline
\end{tabular}

\section{Table 6. 1}

Phase 2: Tallying of Materialism as Compensation for Parental Absence

\begin{tabular}{|c|c|}
\hline Materialism as Compensation & N \\
\hline Prv & 5 \\
\hline Edc & 3 \\
\hline Lf & 2 \\
\hline Lv & 3 \\
\hline
\end{tabular}




\begin{tabular}{|c|c|}
\hline Asc & 3 \\
\hline Cr & 2 \\
\hline Ent & 4 \\
\hline Dny & 2 \\
\hline
\end{tabular}

Table 6. 2

Phase 3: Recurrent Themes

\begin{tabular}{|l|l|}
\hline \multicolumn{1}{|c|}{ Categories } & \multicolumn{1}{c|}{ Sub-categories } \\
\hline \multirow{3}{*}{ Compensated by Benefit } & Provision (CB-Prv) \\
& Education (CB-Edc) \\
& Life (CB-Lf) \\
\hline \multirow{2}{*}{ Compensated by Affection } & $\begin{array}{l}\text { Love (CA-Lv) } \\
\text { Association (CA-Asc) } \\
\text { Care (CA-C) }\end{array}$ \\
\hline Compensated by Divertissement & Entertainment (CD-Ent) \\
\hline Deny & Deny (D-Dny) \\
\hline
\end{tabular}

The presented data showed that the key-participants were expressing three major ways on how materialism compensate for their parents' absence. These were benefit, affection, and divertissement. In majority, the key-participants expressed that their parents' absence was compensated by the benefits they acquire from their parents; (5) responses on Provision, (3) responses on Education, and (2) responses on Life. This was followed by compensation by affection, which they stated that through materialism, parents could show or express their love, association, and care; (8) responses on its subcategories. Others claimed that the materialistic provisions compensate for their parents' absence by divertissement or entertainment; (4) responses on Entertainment. The parental absence was compensated because on how the students live with materialism. Most of the 
students stated that materialism could benefit them, others claimed that materialism is how their parents show their love to them, and few stated that materialism diverts their attention and brings them entertainment.

A study by (Mutie, 2015) claims that parents believe that the best way to compensate their parental absence is to reward excessive material necessities to their children. In a similar way, a research by (Bernardo et al., 2015) has stated OFW families might emphasize the economic benefits to compensate for their separation, which might lead to materialism among children left behind. In connection with this, a study conducted by (Iso, 2017) also stated that most Filipino migrant parents think that the closeness of their relationship cannot be measured by physical relation, but it is how parents do their role to make their children's lives good.

\section{Table 7}

Phase 1: Positive Impacts of Materialism on Grades

\begin{tabular}{|c|l|c|c|}
\hline \multicolumn{2}{|c|}{ Question 4: How does parental materialism impact your grades positively? } \\
\hline $\begin{array}{c}\text { Key- } \\
\text { respondents }\end{array}$ & \multicolumn{1}{|c|}{ Retrieved Data } & Preliminary Codes & Codes \\
\hline Par 1 & $\begin{array}{l}\text { It helps me in understanding and } \\
\text { remembering the lessons by eating } \\
\text { foods that improve brain functions } \\
\text { such as sweet desserts and nuts. }\end{array}$ & Cognitive & Cgn \\
\hline Par 2 & $\begin{array}{l}\text { I am motivated in other subject } \\
\text { because they give me my wish, or at } \\
\text { least I think I must work hard to not } \\
\text { waste what they give. }\end{array}$ & Reward & Rwd \\
\hline Par 3 & $\begin{array}{l}\text { It boosts my confidence and self- } \\
\text { esteem to study well. }\end{array}$ & Self-confidence & Sen \\
\hline
\end{tabular}




\begin{tabular}{|c|c|c|c|}
\hline Par 4 & $\begin{array}{l}\text { It can act as a motivation for me to } \\
\text { do my best in school because it acts } \\
\text { as an exchange, for example if I } \\
\text { improve my grades in my subjects, } \\
\text { they will buy me the book that I've } \\
\text { been wanting for a long time. }\end{array}$ & Reward & Rwd \\
\hline Par 5 & $\begin{array}{l}\text { It is helpful because I am doing } \\
\text { better in school for I know that my } \\
\text { parents are working hard to provide } \\
\text { my needs. }\end{array}$ & Parental & Par \\
\hline Par 6 & $\begin{array}{l}\text { I get higher grades for doing all I } \\
\text { can do to study, so that I can pay off } \\
\text { what they give to me. }\end{array}$ & Parental & Par \\
\hline Par 7 & $\begin{array}{l}\text { It serves as my inspiration to fix my } \\
\text { studies to show that their hard works } \\
\text { are not wasted. }\end{array}$ & Parental & Par \\
\hline \multirow{2}{*}{ Par 8} & \multirow{2}{*}{$\begin{array}{l}\text { Books provided me basic } \\
\text { knowledge, wider vocabulary, and } \\
\text { laptop for making powerpoints and } \\
\text { paperworks. }\end{array}$} & Knowledge & Kwl \\
\hline & & Convenience & Cvn \\
\hline \multirow{2}{*}{ Par 9} & \multirow{2}{*}{$\begin{array}{l}\text { I earn high grades because I don't } \\
\text { want to waste their expenses for my } \\
\text { education. I also have resources to } \\
\text { study well. }\end{array}$} & Parental & Par \\
\hline & & Convenience & Cvn \\
\hline Par 10 & $\begin{array}{l}\text { I think of all their hardships in } \\
\text { working that's why I do all I can to } \\
\text { pass. I want them to be proud. }\end{array}$ & Parental & Par \\
\hline Par 11 & $\begin{array}{l}\text { It helps me acquire high grades and } \\
\text { it makes studying easier, such as } \\
\text { using cell phone. Plus, other art } \\
\text { materials help me in doing projects. }\end{array}$ & Convenience & Cvn \\
\hline Par 12 & $\begin{array}{l}\text { It gives me inspiration and reason to } \\
\text { study well. }\end{array}$ & Incentive & Icn \\
\hline Par 13 & $\begin{array}{l}\text { It helps because I don't need to go to } \\
\text { a computer shop outside to finish } \\
\text { my projects. }\end{array}$ & Convenience & Cvn \\
\hline \multirow{2}{*}{ Par 14} & \multirow{2}{*}{$\begin{array}{l}\text { It makes me review my lessons } \\
\text { easier and communicate to my other } \\
\text { family members not living here in }\end{array}$} & Convenience & Cvn \\
\hline & & Parental & Par \\
\hline
\end{tabular}




\begin{tabular}{|c|c|c|c|}
\hline & our house. & & \\
\hline Par 15 & It acts as a motivational support. & Incentive & Icn \\
\hline Par 16 & $\begin{array}{l}\text { It motivates me to do better in } \\
\text { school. Because whenever I have } \\
\text { projects or assignments, I could } \\
\text { easily access different ideas through } \\
\text { internet using the materials/gadgets } \\
\text { that I have }\end{array}$ & Convenience & Cvn \\
\hline Par 17 & $\begin{array}{l}\text { For me, the child can study well in } \\
\text { school to attain the 'reward'. It } \\
\text { teaches to also strive and work hard } \\
\text { to get what he wants. }\end{array}$ & Reward & Rwd \\
\hline Par 18 & $\begin{array}{l}\text { I am motivated to do things when I } \\
\text { have material provision especially I } \\
\text { know that these are from my } \\
\text { parents. }\end{array}$ & Parental & Par \\
\hline \multirow{2}{*}{ Par 19} & \multirow{2}{*}{$\begin{array}{l}\text { I use gadgets to acquire knowledge } \\
\text { and information. Gadgets also act as } \\
\text { my stress reliever. }\end{array}$} & Knowledge & Kwl \\
\hline & & Stress Reliever & SRl \\
\hline Par 20 & $\begin{array}{l}\text { It becomes a driving force to study } \\
\text { well, knowing that you'll be } \\
\text { rewarded. }\end{array}$ & Reward & Rwd \\
\hline
\end{tabular}

Table 7. 1

Phase 2: Tallying of Positive Impacts of Materialism on Grades

\begin{tabular}{|c|c|}
\hline Positive Impacts on Grades & N \\
\hline Par & 7 \\
\hline Cvn & 6 \\
\hline Rwd & 4 \\
\hline Icn & 1 \\
\hline Cgn & 1 \\
\hline Scn & 1 \\
\hline Kwl & 2 \\
\hline SRl & 1 \\
\hline
\end{tabular}




\section{Table 7. 2}

Phase 3: Recurrent Themes

\begin{tabular}{|l|l|}
\hline \multicolumn{1}{|c|}{ Categories } & \multicolumn{1}{c|}{ Sub-categories } \\
\hline \multirow{3}{*}{ Positive Incentive } & \begin{tabular}{l}
\multicolumn{1}{c|}{ Parental (PI-Par) } \\
Convenience (PI-Cvn) \\
Reward (PI-Rwd) \\
Incentive (PI-Icn)
\end{tabular} \\
\hline \multirow{5}{*}{ Positive Well-being } & Cognitive (PW-Cgn) \\
& Self-confidence (PW-Scn) \\
& Knowledge (PW-Kwl) \\
& Stress Reliever (PW-SRl) \\
\hline
\end{tabular}

The presented data showed that the key-participants expressed two major positive impacts of materialism on their grades; positive effects on their incentive and well-being. The key-participants expressed that materialism helped in their learning for it spurs positive incentive because of their parents, convenience, and reward; a total of (18) responses on its sub-categories. The key-participants also expressed that materialism helped in their learning for it spurs positive well-being through increasing their cognitive performance, boosting their self-confidence, acquiring knowledge, and relieving their stress; a total of (5) responses on its sub-categories. Materialism helped the students in acquiring good grades because of its physical and mental benefit.

The main and utmost reason why the parents decided to work abroad is to send their -children to a preferably school and to sustain their needs in everyday life. Thus, this motivated the students to study hard and pursue their studies. If the students pursue their 
studies, they can make their parents proud and when that happens their parents will support them more and this would lead to further betterment of students' academic performance. (Alegria et al., 2018)

\section{Table 8}

Phase 1: Positive Impacts of Materialism on Educational Resources

\begin{tabular}{|c|c|c|c|}
\hline \multicolumn{4}{|c|}{ Question 5: How does materialism help you to gain more educational resources? } \\
\hline $\begin{array}{l}\text { Key- } \\
\text { respondents }\end{array}$ & Retrieved Data & Preliminary Codes & Codes \\
\hline Par 1 & $\begin{array}{l}\text { It makes studying more convenient } \\
\text { because I have cell phone and other } \\
\text { school resources. }\end{array}$ & Electronic Device & EDv \\
\hline Par 2 & $\begin{array}{l}\text { Anytime I can access the internet by } \\
\text { using my laptop to accomplish } \\
\text { projects, research, and other } \\
\text { activities and of course, to easily } \\
\text { understand lessons. }\end{array}$ & Internet Access & IAc \\
\hline Par 3 & $\begin{array}{l}\text { It can increase my interest in } \\
\text { studying because I have good } \\
\text { materials. And they also give } \\
\text { resources such as laptop that can } \\
\text { help in our research. }\end{array}$ & Electronic Device & EDv \\
\hline Par 4 & $\begin{array}{l}\text { By requesting my parents to buy me } \\
\text { something for school like a school } \\
\text { bag or a nice book about a particular } \\
\text { subject that I'm interested in and isn't } \\
\text { available anywhere near me. }\end{array}$ & Necessity & Ncs \\
\hline Par 5 & $\begin{array}{l}\text { It helps me by buying school } \\
\text { supplies using the money they'e } \\
\text { giving me. }\end{array}$ & Purposeful & Prp \\
\hline Par 6 & $\begin{array}{l}\text { It helps to make studying easier such } \\
\text { as using the laptop for research. }\end{array}$ & Electronic Device & EDv \\
\hline
\end{tabular}




\begin{tabular}{|c|c|c|c|}
\hline Par 7 & $\begin{array}{l}\text { It helps because my parent also } \\
\text { provides the supplies I needed as } \\
\text { they support my study. This is an } \\
\text { advantage. }\end{array}$ & Provision & Prv \\
\hline Par 8 & Books can give cut-outs of drawings. & Purposeful & Prp \\
\hline Par 9 & $\begin{array}{l}\text { My mom works abroad so that they } \\
\text { can give me what I needed in school } \\
\text { esp. the materials so that I can study } \\
\text { well. }\end{array}$ & Provision & Prv \\
\hline Par 10 & $\begin{array}{l}\text { I can request them to buy me } \\
\text { coloring materials or other } \\
\text { uncommon project materials for } \\
\text { school. }\end{array}$ & Necessity & Nes \\
\hline Par 11 & $\begin{array}{l}\text { I can use it to do projects and other } \\
\text { school activities. }\end{array}$ & Purposeful & Prp \\
\hline Par 12 & $\begin{array}{l}\text { They provide complete and good } \\
\text { materials for studying. }\end{array}$ & Provision & Prv \\
\hline Par 13 & $\begin{array}{l}\text { The activities become easier to do, } \\
\text { for example in printing. }\end{array}$ & Electronic Device & EDv \\
\hline Par 14 & $\begin{array}{l}\text { It enhances my creativity and } \\
\text { consequently prepares us in the } \\
\text { future. }\end{array}$ & Purposeful & Prp \\
\hline Par 15 & It connects me into the internet. & Internet Access & IAc \\
\hline \multirow{2}{*}{ Par 16} & \multirow{2}{*}{$\begin{array}{l}\text { It is really a big help. Because it } \\
\text { becomes easier in my part to access } \\
\text { the things that I need online because } \\
\text { of my gadgets. Especially when I } \\
\text { have assignments or projects, the } \\
\text { ideas are just accessible online. }\end{array}$} & Electronic Devices & EDv \\
\hline & & Internet Access & IAc \\
\hline Par 17 & $\begin{array}{l}\text { For me, it helps us to obtain things } \\
\text { that we can use in school so that we } \\
\text { may become motivated or we may } \\
\text { participate in class. }\end{array}$ & Purposeful & Prp \\
\hline Par 18 & $\begin{array}{l}\text { I can use my laptop in doing } \\
\text { research and powerpoint } \\
\text { presentations. }\end{array}$ & Electronic Devices & EDv \\
\hline
\end{tabular}




\begin{tabular}{|l|l|l|l|}
\hline Par 19 & $\begin{array}{l}\text { I get materials whenever I request } \\
\text { my parent about something specific } \\
\text { that I needed in school. }\end{array}$ & Necessity & Ncs \\
\hline Par 20 & $\begin{array}{l}\text { Because they have the capability to } \\
\text { buy me other things, they can also } \\
\text { buy me school supplies/materials. }\end{array}$ & Provision & Prv \\
\hline
\end{tabular}

\section{Table 8. 1}

Phase 2: Tallying of Positive Impacts of Materialism on Educational Resources

\begin{tabular}{|c|c|}
\hline $\begin{array}{c}\text { Positive Impacts on Educational } \\
\text { Resources }\end{array}$ & N \\
\hline Prp & 5 \\
\hline EDv & 6 \\
\hline IAc & 3 \\
\hline Prv & 4 \\
\hline Ncs & 3 \\
\hline
\end{tabular}

\section{Table 8. 2}

Phase 3: Recurrent Themes

\begin{tabular}{|l|l|}
\hline \multicolumn{1}{|c|}{ Categories } & \multicolumn{1}{c|}{ Sub-categories } \\
\hline Attained by Purpose & $\begin{array}{l}\text { Purposeful (AP-Prp) } \\
\text { Electronic Devices (AP-EDv) } \\
\text { Internet Access (AP-IAc) }\end{array}$ \\
\hline Attained by Assurance & Provision (AA-Prv) \\
\hline Attained by Request & Necessity (AR-Ncs) \\
\hline
\end{tabular}


The presented data showed that the key-participants were expressing three major positive impacts of materialism on their educational resources. The key-participants expressed that materialism helped in attaining educational resources by purpose, assurance, and request. Majority of the students purposefully used their materialistic provisions to help on their education such as their electronic devices, internet access, and other materials; (14) responses on its sub-categories. Other key-participants stated that their parents assure their educational resources; (4) responses on Provisions. While some attained educational resources by requesting their necessities to their parents; (3) responses on Necessity. The students had their different ways to use materialism as an educational resource.

Parents often get better paid jobs abroad, providing their children with more financial and educational resources and fostering social and school achievement (Botezat \& Pfeiffer, 2014).

\section{Table 9}

Phase 1: Positive Impacts of Materialism on Self-esteem

\begin{tabular}{|c|c|c|c|}
\hline \multicolumn{4}{|c|}{ Question Number 6: How can materialism positively affect your self-esteem? } \\
\hline $\begin{array}{l}\text { Key- } \\
\text { respondents }\end{array}$ & Retrieved Data & Preliminary Codes & Codes \\
\hline Par 1 & $\begin{array}{l}\text { I can do what I want like wearing } \\
\text { nice clothes. }\end{array}$ & Apparel & Apl \\
\hline Par 2 & $\begin{array}{l}\text { My attitude changes when I get what } \\
\text { I want, sometimes good, sometimes } \\
\text { abusive, it affects my self-esteem } \\
\text { thru thinking that I am financially } \\
\text { stable and proud of what I have. }\end{array}$ & Pleasure & Pls \\
\hline
\end{tabular}




\begin{tabular}{|c|c|c|c|}
\hline Par 3 & $\begin{array}{l}\text { It boosts my confidence because it } \\
\text { brings me joy and happiness. }\end{array}$ & Pleasure & Pls \\
\hline Par 4 & $\begin{array}{l}\text { Materialism can make me feel at } \\
\text { ease and somewhat still important to } \\
\text { the person who's abroad because it } \\
\text { makes me think that they still care } \\
\text { about me and my needs or think of } \\
\text { me even when they're far away and } \\
\text { have other responsibilities. }\end{array}$ & Importance & $\operatorname{Imp}$ \\
\hline Par 5 & $\begin{array}{l}\text { It helps because I recognize that the } \\
\text { sacrifices of my parents are for my } \\
\text { future. }\end{array}$ & Assertion & As \\
\hline Par 6 & $\begin{array}{l}\text { The things my parents give me are } \\
\text { important because I know they work } \\
\text { hard for those. And I value myself, } \\
\text { too, just as I value my things. }\end{array}$ & Self-care & Scr \\
\hline Par 7 & $\begin{array}{l}\text { The materials that they give bring } \\
\text { joy to me. That's why it boosts my } \\
\text { self-esteem. }\end{array}$ & Pleasure & Pls \\
\hline Par 8 & $\begin{array}{l}\text { By receiving gadgets, I can go-with- } \\
\text { the-flow with other people that use } \\
\text { the same gadgets. }\end{array}$ & Brand & Brn \\
\hline Par 9 & $\begin{array}{l}\text { Because my mom isn't here, I } \\
\text { learned how to be independent. I do } \\
\text { this for them. }\end{array}$ & Independence & Ind \\
\hline \multirow{2}{*}{ Par 10} & \multirow{2}{*}{$\begin{array}{l}\text { It is like, my parents give me their } \\
\text { trust by giving me materials. It also } \\
\text { boosts my motivation. }\end{array}$} & Trust & Trs \\
\hline & & Inspiration & Ins \\
\hline Par 11 & $\begin{array}{l}\text { I learn to be more fashionable and } \\
\text { take care of myself. It boosts my } \\
\text { self-esteem when I know that I'm } \\
\text { presentable to look at. }\end{array}$ & Self-care & Scr \\
\hline
\end{tabular}




\begin{tabular}{|c|c|c|c|}
\hline Par 12 & $\begin{array}{l}\text { Because the materials they're giving } \\
\text { are nice and great, they are not } \\
\text { 'local. Others won't tease the } \\
\text { student because of the expensive } \\
\text { things. }\end{array}$ & Societal & Sct \\
\hline Par 13 & $\begin{array}{l}\text { Sometimes it acts as my stress } \\
\text { reliever and I learn how to value my } \\
\text { things. }\end{array}$ & Importance & Imp \\
\hline Par 14 & $\begin{array}{l}\text { It boosts my self-esteem because it } \\
\text { makes my life easier and makes my } \\
\text { feelings well. Moreover, my } \\
\text { confidence depends on the things I } \\
\text { buy or request, because there are } \\
\text { many judgmental people nowadays } \\
\text { that's why I need to choose what } \\
\text { really fits me. }\end{array}$ & Societal & Sct \\
\hline Par 15 & It makes me feel rewarded. & Pleasure & Pls \\
\hline \multirow{2}{*}{ Par 16} & \multirow{2}{*}{$\begin{array}{l}\text { I became more confident, more } \\
\text { updated with the things that are } \\
\text { happening around me and also, I } \\
\text { became more expressive with my } \\
\text { opinions. And I won't feel being left } \\
\text { out. }\end{array}$} & Trend & Trn \\
\hline & & Openness & Opn \\
\hline \multirow{2}{*}{ Par 17} & \multirow{2}{*}{$\begin{array}{l}\text { It affects our confidence because we } \\
\text { receive material provisions from our } \\
\text { parents. It brings us happiness and } \\
\text { importance about the things. }\end{array}$} & Pleasure & Pls \\
\hline & & Importance & Imp \\
\hline \multirow[b]{2}{*}{ Par 18} & \multirow{2}{*}{$\begin{array}{l}\text { I can go with the trend. Also, } \\
\text { whenever I receive materials from } \\
\text { my parent, I become more motivated } \\
\text { to do things I want, and it boosts my } \\
\text { confidence. }\end{array}$} & Trend & Trn \\
\hline & & Inspiration & Ins \\
\hline Par 19 & $\begin{array}{l}\text { I can get along with the people I } \\
\text { know who have branded things. }\end{array}$ & Brand & Brn \\
\hline Par 20 & $\begin{array}{l}\text { Because of my parent's provisions, I } \\
\text { can feel that they love me. }\end{array}$ & Love & Lv \\
\hline
\end{tabular}


Table 9. 1

Phase 2: Tallying of Positive Impacts of Materialism on Self-esteem

\begin{tabular}{|c|c|}
\hline Positive Impacts on Self-esteem & N \\
\hline Pls & 5 \\
\hline Imp & 3 \\
\hline As & 1 \\
\hline Trs & 1 \\
\hline Lv & 1 \\
\hline Ins & 2 \\
\hline Scr & 2 \\
\hline Apl & 1 \\
\hline Opn & 1 \\
\hline Ind & 1 \\
\hline Sct & 2 \\
\hline Brn & 2 \\
\hline Trn & 2 \\
\hline
\end{tabular}

Table 9. 2

Phase 3: Recurrent Themes

\begin{tabular}{|l|l|}
\hline \multicolumn{1}{|c|}{ Categories } & \multicolumn{1}{|c|}{ Sub-categories } \\
\hline \multirow{3}{*}{ Boosted by Conviction } & Pleasure (BC-Pls) \\
& Importance (BC-Imp) \\
& Assertion (BC-As) \\
& Trust (BC-Trs) \\
& Love (BC-Lv) \\
\hline \multirow{3}{*}{ Boosted by Conformity } & Societal (BC-Sct) \\
& Brand (BC-Brn) \\
& Trend (BC-Trn) \\
\hline
\end{tabular}




\begin{tabular}{|l|l|}
\hline \multirow{3}{*}{ Boosted by Assertiveness } & Inspiration (BA-Ins) \\
& Self-care (BA-Scr) \\
Apparel (BA-Apl) \\
Openness (BA-Opn) \\
Independence (BA-Ind) \\
\hline
\end{tabular}

The presented data showed that the key-participants were expressing three major positive impacts of materialism on their self-esteem. The key-participants expressed that materialism helped in boosting their self-esteem by conviction, assertiveness, and conformity. Majority of the key-participants said that having materialistic provisions influence conviction by thinking of the pleasure they experience, their own importance, assertion of their future, and trust and love of their parents; a total of (11) responses on its sub-categories. Other key-participants claimed that materialism helped them boost their self-esteem by having conformity in our society — because of brand and trend; a total of (6) responses on its sub-categories. The key-participants also stated that materialism boosted their assertiveness or confidence because of having inspiration, self-care, apparel, openness, and independence; a total of (5) responses on its sub-categories. The participants use materialism to build their self-esteem in many ways, such as believing in theirselves and conforming to others.

A piece of writing by (Espiritu, 2015) asserts many young people have a strong desire to fit in with their peers. They use things to make themselves happy. They believe that one way to do so is to have the same things that others have. And if they don't, they fear being ousted or left alone. They use things to make themselves happy. 


\section{Table 10}

Phase 1: Positive Impacts of Materialism on Motivation in Learning

\begin{tabular}{|c|c|c|c|}
\hline \multicolumn{4}{|c|}{ Question Number 7: How does materialism drive your motivation to study well? } \\
\hline $\begin{array}{l}\text { Key- } \\
\text { respondents }\end{array}$ & Retrieved Data & Preliminary Codes & Codes \\
\hline Par 1 & $\begin{array}{l}\text { I'm being motivated because it } \\
\text { makes me do things easier such as } \\
\text { compass etc. }\end{array}$ & Convenience & Cvn \\
\hline \multirow{2}{*}{ Par 2} & \multirow{2}{*}{$\begin{array}{l}\text { It gives me motivation because the } \\
\text { materials they give to me will just } \\
\text { be wasted if I don't study well. It } \\
\text { pushes me to study well, and this } \\
\text { helps me to have the things I like } \\
\text { that's why I do better in school. But } \\
\text { not in all subjects though. }\end{array}$} & Reward & Rwd \\
\hline & & Value & Val \\
\hline Par 3 & $\begin{array}{l}\text { I can be motivated like having G- } \\
\text { tech pen to take down notes, and it } \\
\text { can bring improvements in } \\
\text { performance tasks. }\end{array}$ & Convenience & Cvn \\
\hline Par 4 & $\begin{array}{l}\text { Material doesn't matter to me that } \\
\text { much, but it can sometimes drive } \\
\text { my motivation by acting as an } \\
\text { inspiration, something to look } \\
\text { forward to at the end of the tunnel } \\
\text { of hardships and struggle while } \\
\text { studying. }\end{array}$ & Reward & Rwd \\
\hline $\operatorname{Par} 5$ & $\begin{array}{l}\text { I just think about sacrifices abroad. I } \\
\text { can only pay off those by studying } \\
\text { well. }\end{array}$ & Return & Rtr \\
\hline Par 6 & $\begin{array}{l}\text { I become more motivated to study } \\
\text { and listen so that my passing grades } \\
\text { will compensate for their hardships. }\end{array}$ & Return & Rtr \\
\hline $\operatorname{Par} 7$ & $\begin{array}{l}\text { The materials I receive from my } \\
\text { parents give me inspiration because } \\
\text { I see their hardships to give me } \\
\text { those things. }\end{array}$ & Parental & Par \\
\hline Par 8 & $\begin{array}{l}\text { The music from my phone } \\
\text { motivates me. That's the only one. }\end{array}$ & Interest & Int \\
\hline
\end{tabular}




\begin{tabular}{|c|c|c|c|}
\hline Par 9 & $\begin{array}{l}\text { I always remember all of the things } \\
\text { they've done for me and in return, I } \\
\text { will study well. I want them to be } \\
\text { proud. }\end{array}$ & Return & Rtr \\
\hline Par 10 & $\begin{array}{l}\text { I just remember that they worked } \\
\text { hard for the things they gave me. } \\
\text { Those things remind me that I must } \\
\text { study hard so that I can also help } \\
\text { them in the future. }\end{array}$ & Return & Rtr \\
\hline Par 11 & $\begin{array}{l}\text { I am more motivated to do } \\
\text { schoolworks because of the } \\
\text { abundance of things. }\end{array}$ & Convenience & Cvn \\
\hline Par 12 & $\begin{array}{l}\text { A child can think that studying well } \\
\text { can be a way to acquire things } \\
\text { therefore giving a motivation to } \\
\text { study well in school. }\end{array}$ & Reward & Rwd \\
\hline Par 13 & $\begin{array}{l}\text { I am motivated to study well } \\
\text { because of the things they give to } \\
\text { me. }\end{array}$ & Convenience & Cvn \\
\hline Par 14 & $\begin{array}{l}\text { I feel that I needed to be good and } \\
\text { hardworking because they also work } \\
\text { hard to give me those nice things. }\end{array}$ & Return & Rtr \\
\hline Par 15 & $\begin{array}{l}\text { It acts as a reward for me working } \\
\text { hard. }\end{array}$ & Reward & Rwd \\
\hline Par 16 & $\begin{array}{l}\text { It motivates me because it makes } \\
\text { me entertained. And access the } \\
\text { things I need online that could help } \\
\text { me out with my studies. }\end{array}$ & $\begin{array}{l}\text { Convenience } \\
\text { Interest }\end{array}$ & $\begin{array}{l}\text { Cvn } \\
\text { Int }\end{array}$ \\
\hline Par 17 & $\begin{array}{l}\text { It helps because we can be more } \\
\text { diligent in studying, because it } \\
\text { comes with a reward from the } \\
\text { parents. We are being used to this } \\
\text { because they are teaching us to work } \\
\text { hard for the things we want. }\end{array}$ & Reward & Rwd \\
\hline Par 18 & $\begin{array}{l}\text { The things they are giving to me } \\
\text { aren't free, so I need to make them } \\
\text { proud also. }\end{array}$ & Return & Rtr \\
\hline
\end{tabular}




\begin{tabular}{|c|l|c|c|}
\hline Par 19 & $\begin{array}{l}\text { I am motivated to study because my } \\
\text { parents say that in every award I get, } \\
\text { they will give me nice things as a } \\
\text { reward. }\end{array}$ & Reward & Rwd \\
\hline Par 20 & Because reward brings motivation. & Reward & Rwd \\
\hline
\end{tabular}

Table 10. 1

Phase 2: Tallying of Positive Impacts of Materialism on Motivation in Learning

\begin{tabular}{|c|c|}
\hline Positive Impacts on Motivation & N \\
\hline Rwd & 7 \\
\hline Val & 1 \\
\hline Rtr & 6 \\
\hline Cvn & 4 \\
\hline Int & 2 \\
\hline Par & 1 \\
\hline
\end{tabular}

Table 10. 2

Phase 3: Recurrent Themes

\begin{tabular}{|l|l|}
\hline \multicolumn{1}{|c|}{ Categories } & \multicolumn{1}{c|}{ Sub-categories } \\
\hline Motivated by Extraneous Reward & Reward (MER-Rwd) \\
\hline Motivated by Reimbursement & $\begin{array}{l}\text { Value (MR-Val) } \\
\text { Return (MR-Rtr) }\end{array}$ \\
\hline Motivated by Privilege & $\begin{array}{l}\text { Convenience (MP-Cvn) } \\
\text { Interest (MP-Int) } \\
\text { Parental (MP-Par) }\end{array}$ \\
\hline
\end{tabular}


The presented data showed that the key-participants were expressing three major positive impacts of materialism on their motivation in learning. The key-participants expressed that materialism motivated them to study well by extraneous reward, sense of reimbursement, and privilege. The key-participants expressed that they were motivated to study because of the reward that their parents are giving them, while others expressed that they were being motivated because they want to reimburse or pay-off the hardships of their parents. The key-participants also claimed that they were motivated by the privilege (such as having convenience, interest, and parental inspiration) brought by the materialistic provisions from their parents. Each of the categories gained a total of (7) responses on their respective sub-categories. The students were motivated because of the reward they receive, parental inspiration, and privilege.

According to one study conducted by (Richins \& Chaplin, 2015), parents use material goods every day in their interactions with children. Parents may give reward to their children because of their accomplishments. Additionally, (Alegria et al., 2018) claimed that the main and utmost reason why the parents decided to work abroad is to send their children to a preferably school and to sustain their needs in everyday life. Thus, this motivated the students to study hard and pursue their studies. If the students pursue their studies, they can make their parents proud and when that happens their parents will support them more and this would lead to further betterment of students' academic performance. 


\section{Table 11}

Phase 1: Positive Impacts of Materialism on Class Participation

\begin{tabular}{|c|c|c|c|}
\hline $\begin{array}{l}\text { Key- } \\
\text { respondents }\end{array}$ & Retrieved Data & Preliminary Codes & Codes \\
\hline Par 1 & $\begin{array}{l}\text { It helps me to contribute when I am } \\
\text { in a group work like giving necessary } \\
\text { money. }\end{array}$ & Contribution & Cnt \\
\hline Par 2 & $\begin{array}{l}\text { I can easily access my cellphone } \\
\text { when the teachers give activities. }\end{array}$ & Convenience & Cvn \\
\hline Par 3 & $\begin{array}{l}\text { I can acquire new books or school } \\
\text { materials for studying. }\end{array}$ & Convenience & Cvn \\
\hline Par 4 & $\begin{array}{l}\text { By acting as a motivation and driving } \\
\text { me to act well and do my best } \\
\text { because of the reward that I can get } \\
\text { when I do well in class. }\end{array}$ & Reward & Rwd \\
\hline Par 5 & $\begin{array}{l}\text { I just think of their sacrifices. And } \\
\text { This is for my parents, so I need to } \\
\text { excel. }\end{array}$ & Parental & Par \\
\hline Par 6 & $\begin{array}{l}\text { I often recite because of the things } \\
\text { my parents give me. }\end{array}$ & Inspiration & Ins \\
\hline Par 7 & $\begin{array}{l}\text { I study to return their hardship and } \\
\text { make them happy. }\end{array}$ & Parental & Par \\
\hline Par 8 & $\begin{array}{l}\text { For example, there was an activity in } \\
\text { our group chat I can participate with } \\
\text { the rest of the class because I have } \\
\text { cell phone. }\end{array}$ & Convenience & Cvn \\
\hline Par 9 & $\begin{array}{l}\text { I participate, I listen, I answer and } \\
\text { recite, and I cooperate in the } \\
\text { activities so that I'll have good } \\
\text { grades because my mother gives me } \\
\text { reward. }\end{array}$ & Reward & Rwd \\
\hline
\end{tabular}




\begin{tabular}{|c|c|c|c|}
\hline Par 10 & $\begin{array}{l}\text { It helps when I don't know } \\
\text { something, I can just search it. Or I } \\
\text { can have an advance reading. }\end{array}$ & Convenience & Cvn \\
\hline Par 11 & $\begin{array}{l}\text { Because of the reward, you will do } \\
\text { better in class. }\end{array}$ & Reward & Rwd \\
\hline \multirow[t]{2}{*}{ Par 12} & \multirow{2}{*}{$\begin{array}{l}\text { As I said, the thought that our parents } \\
\text { are working hard in abroad for us } \\
\text { gives inspiration. Therefore, } \\
\text { strengthening the motivation to } \\
\text { participate class. Materialism also } \\
\text { motivates me to participate in class } \\
\text { sometimes. }\end{array}$} & Parental & Par \\
\hline & & Inspiration & Ins \\
\hline Par 13 & $\begin{array}{l}\text { I can easily know the meaning of } \\
\text { deep words. }\end{array}$ & Convenience & Cvn \\
\hline \multirow{2}{*}{ Par 14} & \multirow{2}{*}{$\begin{array}{l}\text { It eases my feeling and it gives me } \\
\text { confidence. }\end{array}$} & Convenience & Cvn \\
\hline & & Confidence & Cnf \\
\hline \multirow{2}{*}{ Par 15} & \multirow{2}{*}{$\begin{array}{l}\text { It makes me more active in classes } \\
\text { because it helps me in my studies, } \\
\text { and it acts as a reward. }\end{array}$} & Convenience & Cvn \\
\hline & & Reward & Rwd \\
\hline \multirow{2}{*}{ Par 16} & \multirow{2}{*}{$\begin{array}{l}\text { Because of the materials that I have, } \\
\text { especially my gadgets, I became } \\
\text { more motivated and it gives me a } \\
\text { positive aura inside the class } \\
\text { specially in participating inside the } \\
\text { school activities with all the } \\
\text { knowledge that I am getting with this } \\
\text { material. Because of the influence of } \\
\text { the online world, I became more } \\
\text { reasonable and knowledgeable at } \\
\text { some point. Because of this, I became } \\
\text { more expressive in graded recitation } \\
\text { and could finally show my creativity } \\
\text { confidently. }\end{array}$} & Convenience & Cvn \\
\hline & & Confidence & Cnf \\
\hline
\end{tabular}




\begin{tabular}{|c|l|l|c|}
\hline Par 17 & $\begin{array}{l}\text { It positively affects because we get } \\
\text { along with other people. We can } \\
\text { share these to them, and we can be } \\
\text { confident to join different activities } \\
\text { in our school. It can also cause } \\
\text { communication and having friends. }\end{array}$ & Confidence & Cnf \\
\hline Par 18 & $\begin{array}{l}\text { I know that at the end of the day, } \\
\text { everything is worth it. }\end{array}$ & Inspiration & Ins \\
\hline Par 19 & $\begin{array}{l}\text { It motivates me because I have things } \\
\text { to use if there are activities. }\end{array}$ & Convenience & Cvn \\
\hline Par 20 & $\begin{array}{l}\text { It motivates me to do my best in } \\
\text { class. }\end{array}$ & Inspiration & Ins \\
\hline
\end{tabular}

\section{Table 11. 1}

Phase 2: Tallying of Positive Impacts of Materialism on Class Participation

\begin{tabular}{|c|c|}
\hline Positive Impacts on Participation & N \\
\hline Cvn & 9 \\
\hline Cnf & 3 \\
\hline Cnt & 1 \\
\hline Rwd & 4 \\
\hline Par & 4 \\
\hline Ins & 4 \\
\hline
\end{tabular}

Table 11. 2

Phase 3: Recurrent Themes

\begin{tabular}{|l|l|}
\hline \multicolumn{1}{|c|}{ Categories } & \multicolumn{1}{c|}{ Sub-categories } \\
\hline \multirow{3}{*}{ Encouraged by Advantage } & Convenience (EA-Cvn) \\
& Confidence (EA-Cnf) \\
& Contribution (EA-Cnt) \\
\hline
\end{tabular}




\begin{tabular}{|l|l|}
\hline & Reward (EI-Rwd) \\
Encouraged by Inducement & Parental (EI-Par) \\
& Inspiration (EI-Ins) \\
\hline
\end{tabular}

The presented data shows that the key-participants were expressing two major positive impacts of materialism on their class participation. The key-participants expressed that materialism helps improve their class participation because it acts as an advantage and inducement. Materialism is advantageous for them to have convenience, confidence, and financial contribution in the class; a total of (13) responses on its subcategories. Materialism also induces them to participate better because it acts as an inspiration to them, such as receiving reward or parental inspiration; a total of (12) responses on its sub-categories. Students tended to participate more in class because of the advantage and motivation from materialism.

Similarly, the main and utmost reason why the parents decided to work abroad is to send their children to a preferably school and to sustain their needs in everyday life. Thus, this motivated the students to study hard and pursue their studies. (Alegria et al., 2018)

\section{Table 12}

Phase 1: Negative Impacts of Materialism on Grades

\begin{tabular}{|c|l|l|c|}
\hline \multicolumn{3}{|c|}{ Question 9: How does parental materialism impact your grades negatively? } \\
\hline $\begin{array}{c}\text { Key- } \\
\text { respondents }\end{array}$ & \multicolumn{1}{|c|}{ Retrieved Data } & Preliminary Codes & Codes \\
\hline Par 1 & $\begin{array}{l}\text { I might give more time using my phone } \\
\text { than studying. }\end{array}$ & Electronic device & EDv \\
\hline
\end{tabular}




\begin{tabular}{|c|c|c|c|}
\hline Par 2 & $\begin{array}{l}\text { Sometimes I just focus on their } \\
\text { luxurious offerings one example is } \\
\text { cycling, so it's just that I disregard my } \\
\text { studies. }\end{array}$ & Deflection & Dfl \\
\hline Par 3 & $\begin{array}{l}\text { I sometimes agitated about the things } \\
\text { they're about to give, I feel distracted. }\end{array}$ & Distress & Dst \\
\hline Par 4 & $\begin{array}{l}\text { It can impact me negatively if the } \\
\text { things that they've bought me to } \\
\text { compensate for their absence are bad } \\
\text { for my grades, for example something } \\
\text { that I could get addicted to like a game } \\
\text { or something that I will probably } \\
\text { prioritize instead of my studies. }\end{array}$ & Deflection & Dfl \\
\hline Par 5 & $\begin{array}{l}\text { It affects negatively in my education } \\
\text { because it reminds me that I am not } \\
\text { with my parents. }\end{array}$ & Distress & Dst \\
\hline Par 6 & It doesn't affect negatively. & Deny & Dny \\
\hline Par 7 & $\begin{array}{l}\text { Sometimes I do not study well because } \\
\text { of the things that they give to me. For } \\
\text { example, cell phone and laptop. I } \\
\text { prioritize playing games than to study. }\end{array}$ & Electronic Device & EDv \\
\hline Par 8 & $\begin{array}{l}\text { Gadgets distract me in every way, also } \\
\text { reducing my time to sleep. }\end{array}$ & Electronic Device & EDv \\
\hline Par 9 & $\begin{array}{l}\text { It doesn't affect negatively because I } \\
\text { don't want to disappoint my mom, so I } \\
\text { study really hard. }\end{array}$ & Deny & Dny \\
\hline Par 10 & $\begin{array}{l}\text { I give more attention on materialistic } \\
\text { things than studying. In most cases, } \\
\text { using cell phone. }\end{array}$ & Electronic Device & EDv \\
\hline Par 11 & $\begin{array}{l}\text { Overuse of gadgets. I give more } \\
\text { attention to those things that studying. }\end{array}$ & Electronic Device & EDv \\
\hline Par 12 & $\begin{array}{l}\text { It can also give reasons not to study } \\
\text { because of being dependent to what the } \\
\text { parents give, that they could provide } \\
\text { everything that the child needs. }\end{array}$ & Reliance & Rlc \\
\hline Par 13 & $\begin{array}{l}\text { Sometimes I forget to do assignments } \\
\text { because of watching in YouTube. }\end{array}$ & Electronic device & EDv \\
\hline
\end{tabular}




\begin{tabular}{|c|l|c|c|}
\hline Par 14 & $\begin{array}{l}\text { It affects me when sometimes I do not } \\
\text { have sufficient materials in school. }\end{array}$ & Insufficiency & Isf \\
\hline Par 15 & $\begin{array}{l}\text { It always disrupts my concentration in } \\
\text { my studies. }\end{array}$ & Out of focus & OFs \\
\hline Par 16 & $\begin{array}{l}\text { Nothing. Because I am always doing } \\
\text { my best even if there's no materialism } \\
\text { involved. }\end{array}$ & Deny & Dny \\
\hline Par 17 & $\begin{array}{l}\text { If it is being abused like being spoiled. } \\
\text { Or sometimes, materialism makes } \\
\text { students dependable on the things and } \\
\text { will consequently ignore their studies. }\end{array}$ & Deflection & Reliance \\
\hline Par 18 & $\begin{array}{l}\text { I admit that when I use laptop/cell } \\
\text { phone, I can be tempted to use FB and } \\
\text { just ignore my works. }\end{array}$ & Electronic Devices & EDv \\
\hline Par 19 & $\begin{array}{l}\text { I often browse the internet than to do } \\
\text { school activities. }\end{array}$ & Electronic Devices & EDv \\
\hline Par 20 & It becomes a distraction in studying. & Out of focus & OFs \\
\hline
\end{tabular}

Table 12. 1

Phase 2: Tallying of Negative Impacts of Materialism on Grades

\begin{tabular}{|c|c|}
\hline Negative Impacts on Grades & N \\
\hline EDv & 8 \\
\hline Dfl & 3 \\
\hline OFs & 2 \\
\hline Dst & 2 \\
\hline Rlc & 2 \\
\hline Isf & 1 \\
\hline Dny & 3 \\
\hline
\end{tabular}




\section{Table 12. 2}

Phase 3: Recurrent Themes

\begin{tabular}{|l|l|}
\hline \multicolumn{1}{|c|}{ Categories } & \multicolumn{1}{c|}{ Sub-categories } \\
\hline Cause of Deflection & $\begin{array}{l}\text { Electronic Device (CD-EDv) } \\
\text { Deflection (CD-Dfl) }\end{array}$ \\
\hline Cause of Disturbance & $\begin{array}{l}\text { Out of Focus (CD-OFs) } \\
\text { Distress (CD-Dst) }\end{array}$ \\
\hline Cause of Demotivation & Reliance (CD-Rlc) \\
\hline Cause of Insufficiency & Insufficiency (CI-Isf) \\
\hline Deny & Deny (D-Dny) \\
\hline
\end{tabular}

The presented data showed that the key-participants were expressing four major negative impacts of materialism on their grades. The key-participants expressed that materialism caused deflection, disturbance, demotivation, and insufficiency. The keyparticipants expressed that materialism deflected them from studying and they choose to prioritize their materialistic provisions, especially electronic devices, than to prioritize their studies; a total of (11) responses on its sub-categories. Materialism also caused disturbance. The key-participants claimed that materialism made them out of focused or distressed; (2) responses on Out of Focus and (2) responses on Distress. Some keyparticipants also confessed being demotivated because of just merely relying on their materialistic provisions instead of studying hard and not being dependable; (2) responses on Reliance. A key-participant stated that materialism causesd insufficiency on his 
educational resources. The students' grades were affected negatively by materialism mainly because of prioritizing materialistic possessions.

(Mutie, 2015) claims that when parents superfluously provide their children with material things, the discipline of children may erode.

\section{Table 13}

Phase 1: Negative Impacts of Materialism on Educational Resources

Question 10: What are the bad effects of materialism on your educational resources?

\begin{tabular}{|c|l|c|c|}
\hline $\begin{array}{c}\text { Key- } \\
\text { respondents }\end{array}$ & \multicolumn{1}{|c|}{ Retrieved Data } & Codes \\
\hline Par 1 & $\begin{array}{l}\text { I sometimes lend my things to others } \\
\text { and they won't return it back } \\
\text { anymore. }\end{array}$ & Taken Advantage & TAd \\
\hline Par 2 & $\begin{array}{l}\text { It negatively affects because } \\
\text { sometimes I give more of my } \\
\text { attention in the materials than to } \\
\text { study. }\end{array}$ & $\begin{array}{l}\text { I might be envy with other students' } \\
\text { things or be ashamed of my things } \\
\text { and lose confidence in studying. }\end{array}$ & Dissatisfaction \\
\hline Par 3 & $\begin{array}{l}\text { People may view me as a showoff or } \\
\text { rich kid and just depend on me to do } \\
\text { the project or to pay for expenses on } \\
\text { school projects and such and people } \\
\text { may take advantage of my resources } \\
\text { and not see them as valuable or } \\
\text { something to take good care of } \\
\text { because I have nothing to lose and I } \\
\text { can just easily buy a new one. }\end{array}$ & $\begin{array}{l}\text { Taken Advantage } \\
\text { I pity my parents because they work } \\
\text { very hard to buy me things I think } \\
\text { buying school supplies is very costly. }\end{array}$ & Dsf \\
\hline Par 5 4 & $\begin{array}{l}\text { It doesn't affect negatively. } \\
\text { Par } 6\end{array}$ & DAd \\
\hline
\end{tabular}




\begin{tabular}{|c|c|c|c|}
\hline Par 7 & $\begin{array}{l}\text { I am used to have educational } \\
\text { resources in our house already } \\
\text { because of my parent's provisions. } \\
\text { That's why I do not find it } \\
\text { comfortable to request them new } \\
\text { things. And sometimes instead of } \\
\text { using my phone in helping to study, it } \\
\text { becomes a distraction. }\end{array}$ & Out of Focus & OFs \\
\hline Par 8 & $\begin{array}{l}\text { I prioritize playing games rather than } \\
\text { studying. }\end{array}$ & Out of focus & OFs \\
\hline Par 9 & $\begin{array}{l}\text { Sometimes I lose my materials in } \\
\text { school when I bring them. That's why } \\
\text { it is better not to use them. }\end{array}$ & Loss & Lss \\
\hline Par 10 & $\begin{array}{l}\text { The things I request for educational } \\
\text { purposes, such as cellphone, just } \\
\text { mainly become entertainment instead } \\
\text { of using it for education. }\end{array}$ & Out of focus & OFs \\
\hline Par 11 & It doesn't negatively affect. & Deny & Dny \\
\hline Par 12 & $\begin{array}{l}\text { Sometimes it brings high expectation } \\
\text { towards the materials that can cause } \\
\text { disconnection of the student to the } \\
\text { parents. }\end{array}$ & Expectations & Exp \\
\hline Par 13 & $\begin{array}{l}\text { It doesn't affect me, but sometimes } \\
\text { other students just use gadgets to play } \\
\text { games, which is not allowed in } \\
\text { school. }\end{array}$ & Deny & Dny \\
\hline Par 14 & $\begin{array}{l}\text { The laptop is heavy. And sometimes, } \\
\text { instead of making my work easier, I } \\
\text { become more stressed because of } \\
\text { modern technology it is complicated } \\
\text { to use. }\end{array}$ & Inconvenience & Icv \\
\hline Par 15 & It just makes us dependent in it. & Reliance & Rlc \\
\hline Par 16 & $\begin{array}{l}\text { Both motivation and sometimes } \\
\text { distractions. But it depends on your } \\
\text { controlling skills, and how will you } \\
\text { handle the situation. }\end{array}$ & Out of focus & OFs \\
\hline Par 17 & $\begin{array}{l}\text { The negative effect of materialism to } \\
\text { me, is when I lend my things to }\end{array}$ & Loss & Lss \\
\hline
\end{tabular}




\begin{tabular}{|c|l|c|c|}
\hline & $\begin{array}{l}\text { others, it will rarely come back to me. } \\
\text { And sometimes, I misplace it and lose } \\
\text { it. }\end{array}$ & Taken advantage & TAd \\
\hline Par 18 & $\begin{array}{l}\text { I give more attention to my laptop } \\
\text { and cellphone, sometimes I do not } \\
\text { read my books anymore. }\end{array}$ & Out of focus & OFs \\
\hline Par 19 & $\begin{array}{l}\text { They buy me too much. Some } \\
\text { materials aren't really needed in } \\
\text { school, they are just being unused. }\end{array}$ & Excessive & Exc \\
\hline Par 20 & $\begin{array}{l}\text { The money is just being wasted } \\
\text { because they buy me too many } \\
\text { materials. }\end{array}$ & Excessive & Exc \\
\hline
\end{tabular}

\section{Table 13. 1}

Phase 2: Tallying of Negative Impacts of Materialism on Educational Resources

\begin{tabular}{|c|c|}
\hline $\begin{array}{c}\text { Negative Impacts on Educational } \\
\text { Resources }\end{array}$ & $\mathrm{N}$ \\
\hline OFs & 6 \\
\hline Lss & 2 \\
\hline Exc & 2 \\
\hline TAd & 2 \\
\hline Exp & 1 \\
\hline Dsf & 1 \\
\hline Cst & 1 \\
\hline Rlc & 1 \\
\hline Rtc & 1 \\
\hline Icv & 1 \\
\hline Dny & 3 \\
\hline
\end{tabular}

Table 13. 2

Phase 3: Recurrent Themes

\begin{tabular}{|l|l|}
\hline \multicolumn{1}{|c|}{ Categories } & \multicolumn{1}{c|}{ Sub-categories } \\
\hline Affected by Misusage & Out of Focus (AM-OFs) \\
\hline
\end{tabular}




\begin{tabular}{|l|l|}
\hline Affected by Immoderation & $\begin{array}{l}\text { Excessive (AI-Exc) } \\
\text { Costly (AI-Cst) }\end{array}$ \\
\hline Affected by Exploitation & Taken Advantage (AE-TAd) \\
\hline Affected by Carelessness & Loss (AC-Lss) \\
\hline Affected by Dissatisfaction & $\begin{array}{l}\text { Expectations (AD-Exp) } \\
\text { Dissatisfaction (AD-Dsf) }\end{array}$ \\
\hline Affected by Dependence & Reliance (AD-Rlc) \\
\hline Affected by Reticence & Reticent (AR-Rtc) \\
\hline Affected by Difficulty & Inconvenience (AD-Icv) \\
\hline Deny & Deny (AD-Dny) \\
\hline
\end{tabular}

Based on the presented data, eight major negative impacts of materialism on educational resources were shown by the participants. The key-participants expressed that they were affected by misusage, exploitation, carelessness, immoderation, dependence, dissatisfaction, reticence, and difficulty. The key-participants expressed that they misuse their resources by just using them for recreation instead of using them for education; (6) responses on Out of Focus. The key-participants also claimed immoderation on their educational resources because their parents were giving them costly and excessive unnecessary educational materials. (2) responses on Excessive and (1) response on Costly. Others experienced exploitation from their fellow students because of the materials they have; (2) responses on Taken Advantage. The keyparticipants also showed carelessness for losing the materials they have; (2) responses on Loss. Some claimed that they were dissatisfied by the things they receive because the materials did not meet their expectations; a total of (2) responses on its sub-categories. Some also expressed being dependable on the materialistic provisions, being reticent or 
shy for requesting resources, and having difficulties due to the inconvenience of the materialistic provisions; each of the categories gained a total of (1) response on their respective sub-categories.

\section{Table 14}

Phase 1: Negative Impacts of Materialism on Self-esteem

\begin{tabular}{|c|c|c|c|}
\hline \multicolumn{4}{|c|}{ Question 11: Give some negative impacts of materialism on your self-esteem. } \\
\hline $\begin{array}{c}\text { Key- } \\
\text { respondents }\end{array}$ & Retrieved Data & Preliminary Codes & Codes \\
\hline Par 1 & $\begin{array}{l}\text { It can affect attitude by being } \\
\text { boastful. }\end{array}$ & Boastful & Bsf \\
\hline \multirow{3}{*}{ Par 2} & \multirow{3}{*}{$\begin{array}{l}\text { Sometimes I become boastful, but I } \\
\text { can control it because I feel } \\
\text { ashamed that it is not really my } \\
\text { money. Sometimes abusive and not } \\
\text { being showy. }\end{array}$} & Boastful & Bsf \\
\hline & & Abusive & Abv \\
\hline & & Dependence & Dpd \\
\hline Par 3 & $\begin{array}{l}\text { Being ashamed and feeling } \\
\text { depressed. Because sometimes } \\
\text { others become bully toward the } \\
\text { disagreeable material. }\end{array}$ & Shamefulness & Shm \\
\hline Par 4 & $\begin{array}{l}\text { It negatively affects me by making } \\
\text { me feel bad about myself because as } \\
\text { they supply me with material they } \\
\text { sometimes also use that against me } \\
\text { whenever I act out or get emotional } \\
\text { or something saying I just acted } \\
\text { nicely because I wanted them to buy } \\
\text { me something and guilt tripping, } \\
\text { using material to gain something } \\
\text { from me, for bribing and such. It } \\
\text { can also make me feel bad because } \\
\text { it makes me feel that I am a shallow } \\
\text { person that can be easily bought or } \\
\text { satisfied with material even when } \\
\text { I'm not; it can also make me feel } \\
\text { like a bad daughter for not returning } \\
\text { their efforts and buying them stuff } \\
\text { or doing something nice for them. }\end{array}$ & Actions & Act \\
\hline
\end{tabular}




\begin{tabular}{|c|c|c|c|}
\hline Par 5 & $\begin{array}{l}\text { It affects because I feel like our } \\
\text { relationship is weakening because } \\
\text { they're not here with me. }\end{array}$ & Relational & $\mathrm{R} \ln$ \\
\hline Par 6 & It doesn't affect. & Deny & Dny \\
\hline Par 7 & $\begin{array}{l}\text { I might become used to the } \\
\text { materials and I might be dependent } \\
\text { to others always. It will worsen self- } \\
\text { esteem because of not knowing how } \\
\text { to work hard for the personal wants. }\end{array}$ & Dependence & Dpd \\
\hline Par 8 & $\begin{array}{l}\text { By playing inside of my room, I } \\
\text { create a barrier that distances me to } \\
\text { other people. }\end{array}$ & Remoteness & Rmt \\
\hline \multirow{2}{*}{ Par 9} & \multirow{2}{*}{$\begin{array}{l}\text { I avoid doing mistakes because I } \\
\text { don't want them to be disappointed. } \\
\text { Because they're working abroad and } \\
\text { I'm only living with my aunt, I can't } \\
\text { tell them my problems. }\end{array}$} & Perfection & Pfc \\
\hline & & Remoteness & Rmt \\
\hline Par 10 & $\begin{array}{l}\text { It confines me from talking to other } \\
\text { people in person that's why I lost } \\
\text { my confidence to speak up. They } \\
\text { consider that I am not important } \\
\text { because they think I don't receive } \\
\text { any attention. }\end{array}$ & Remoteness & Rmt \\
\hline Par 11 & $\begin{array}{l}\text { Sometimes I give more importance } \\
\text { on the things and it makes me also } \\
\text { feel like I don't deserve those. }\end{array}$ & Self-doubt & Sdt \\
\hline Par 12 & $\begin{array}{l}\text { The child might be boastful because } \\
\text { of the luxury received from the } \\
\text { OFW parent. }\end{array}$ & Boastful & Bsf \\
\hline Par 13 & $\begin{array}{l}\text { It doesn't negatively affect my self- } \\
\text { esteem. But sometimes other people } \\
\text { forget to do things like using the } \\
\text { soap. }\end{array}$ & Self-negligence & Snl \\
\hline \multirow{2}{*}{ Par 14} & \multirow{2}{*}{$\begin{array}{l}\text { I give more attention to the } \\
\text { materials than to myself. It ruins } \\
\text { socialization with other people. }\end{array}$} & Self-negligence & Snl \\
\hline & & Remoteness & Rmt \\
\hline
\end{tabular}




\begin{tabular}{|c|c|c|c|}
\hline Par 15 & $\begin{array}{l}\text { It distracts me from my } \\
\text { responsibilities because it takes my } \\
\text { time too much. }\end{array}$ & Self-negligence & Snl \\
\hline Par 16 & $\begin{array}{l}\text { Can't think of a negative impact, but } \\
\text { with others, they are becoming more } \\
\text { unreasonable because of the things } \\
\text { that they are seeing online for using } \\
\text { their gadgets. }\end{array}$ & Irrational & Irr \\
\hline \multirow{3}{*}{ Par 17} & \multirow{3}{*}{$\begin{array}{l}\text { Being used to having materialistic } \\
\text { provisions and being dependent in } \\
\text { receiving such. Always looking for } \\
\text { reward or pay-off in different } \\
\text { things. Lack of satisfaction on the } \\
\text { materials they are giving. Self- } \\
\text { negligence because of things they } \\
\text { give like gadgets. Being abusive in } \\
\text { using the things. }\end{array}$} & Dependence & Dpd \\
\hline & & Self-negligence & Snl \\
\hline & & Discontentment & Dsc \\
\hline \multirow{2}{*}{ Par 18} & \multirow{2}{*}{$\begin{array}{l}\text { It makes me selfish. I overuse or } \\
\text { misuse my things. }\end{array}$} & Egotistical & Egt \\
\hline & & Abusive & $\mathrm{Abv}$ \\
\hline Par 19 & $\begin{array}{l}\text { My insecurity and pride increase. } \\
\text { I'm also losing my interest in other } \\
\text { people. }\end{array}$ & Egotistical & Egt \\
\hline Par 20 & Greediness. & Greediness & Grd \\
\hline
\end{tabular}

Table 14. 1

Phase 2: Tallying of Negative Impacts of Materialism on Self-esteem

\begin{tabular}{|c|c|}
\hline Negative Impacts on Self-esteem & N \\
\hline Bsf & 3 \\
\hline Abv & 2 \\
\hline Pfc & 1 \\
\hline Irr & 1 \\
\hline Dsc & 1 \\
\hline
\end{tabular}




\begin{tabular}{|c|c|}
\hline Grd & 1 \\
\hline Egt & 2 \\
\hline Dpd & 3 \\
\hline Shm & 1 \\
\hline Act & 1 \\
\hline Rln & 1 \\
\hline Tsd & 1 \\
\hline Sdt & 1 \\
\hline Snl & 4 \\
\hline Rmt & 4 \\
\hline Dny & 1 \\
\hline
\end{tabular}

Table 14. 2

Phase 3: Recurrent Themes

\begin{tabular}{|l|l|}
\hline \multicolumn{1}{|c|}{ Categories } & \multicolumn{1}{|c|}{ Sub-categories } \\
\hline \multirow{4}{*}{ Driven by Egotism } & Boastful (DE-Bsf) \\
& Abusive (DE-Abv) \\
& Perfection (DE-Pfc) \\
& Irrational (DE-Irr) \\
& Discontentment (DE-Dsc) \\
& Greediness (DE-Grd) \\
& Egotistical (DE-Egt) \\
\hline & Dependence (DG-Dpd) \\
& Shamefulness (DG-Shm) \\
& Actions (DG-Act) \\
& Relational (DG-Rln) \\
& Teased (DG-Tsd) \\
& Self-doubt (DG-Sdt) \\
& \\
\hline
\end{tabular}




\begin{tabular}{|l|l|}
\hline Driven by Self-negligence & Self-negligence (DS-Snl) \\
\hline Driven by Poor Socialization & Remoteness (DPS-Rmt) \\
\hline Deny & Deny (D-Dny) \\
\hline
\end{tabular}

Based on the presented data, four major negative impacts of materialism on selfesteem were shown by the participants. Key-participants expressed that they were driven by egotism, guilt, self-negligence, and poor socialization because of materialism. In majority, students expressed that they were driven by egotism just as by being boastful, abusive, perfectionists, irrational, discontented, and greedy; a total of (11) responses on its sub-categories. The respondents also claimed that materialism made them feel guilty because of being dependable, shameful, teased, and having self-doubt. Others are also guilt-ridden because of their actions and their relationship with their parents. This category gained a total of (8) responses on its sub-categories. Some also stated that they experienced self-negligence and poor socialization. They tended to ignore their selves or other people because of prioritizing materialism; each of the categories gained a total of (4) responses on their respective sub-categories. Materialism effectuates undesirable behaviors among the students that's why it could lower their self-esteem.

A study by (Mutie, 2015) claims that when parents superfluously provide their children with material things, the discipline of children and the mutual cohesiveness that is supposed to exist between parents and children may greatly erode. A study conducted by (Iso, 2017) stated that children are vulnerable to lots of problem and becoming selfdoubting. 


\section{Table 15}

Phase 1: Negative Impacts of Materialism on Motivation in Learning

\begin{tabular}{|c|c|c|c|}
\hline \multicolumn{4}{|c|}{ Question 12: How does materialism distract you from studying? } \\
\hline Key-respondents & Retrieved Data & $\begin{array}{l}\text { Preliminary } \\
\text { Codes }\end{array}$ & Codes \\
\hline Par 1 & $\begin{array}{l}\text { Cell phone causes bad effects if it is not } \\
\text { used with limitations. }\end{array}$ & Limitless & Lml \\
\hline Par 2 & $\begin{array}{l}\text { Sometimes I just focus on their luxury } \\
\text { offerings, one example is cycling, so it's } \\
\text { just that I neglected my studies. }\end{array}$ & Negligence & $\mathrm{Ngl}$ \\
\hline Par 3 & $\begin{array}{l}\text { We can become agitated and distracted. } \\
\text { For example, if I have new plaything in } \\
\text { the house, I would be excited to go home } \\
\text { and forget my studies without being } \\
\text { aware of it. }\end{array}$ & Agitation & Agt \\
\hline Par 4 & $\begin{array}{l}\text { It can act as a distraction when I'm too } \\
\text { focused on the material that I will get } \\
\text { instead of the act that I have to do to get } \\
\text { it such as studying. }\end{array}$ & Agitation & Agt \\
\hline Par 5 & $\begin{array}{l}\text { Because when I study, I think of their } \\
\text { absence. They're not here to help and } \\
\text { guide me. }\end{array}$ & Anxiety & Anx \\
\hline Par 6 & $\begin{array}{l}\text { I often give attention more to the material } \\
\text { provisions. And because of that, } \\
\text { sometimes, I cannot review well. }\end{array}$ & Engrossment & Egm \\
\hline Par 7 & $\begin{array}{l}\text { It becomes distraction sometimes because } \\
\text { I give more attention to those and I } \\
\text { neglect my studies and I can't focus } \\
\text { anymore. }\end{array}$ & Negligence & $\mathrm{Ngl}$ \\
\hline
\end{tabular}




\begin{tabular}{|c|c|c|c|}
\hline Par 8 & $\begin{array}{l}\text { Addiction in playing games, I lose time } \\
\text { to study. }\end{array}$ & Engrossment & Egm \\
\hline Par 9 & $\begin{array}{l}\text { Because of the electronic devices they } \\
\text { give, I give more attention to those } \\
\text { instead of doing homeworks. }\end{array}$ & Negligence & $\mathrm{Ngl}$ \\
\hline Par 10 & $\begin{array}{l}\text { Sometimes using cell phone during } \\
\text { classes before. }\end{array}$ & Negligence & $\mathrm{Ngl}$ \\
\hline Par 11 & $\begin{array}{l}\text { I give more attention to it sometimes, } \\
\text { than to study. }\end{array}$ & Negligence & $\mathrm{Ngl}$ \\
\hline Par 12 & $\begin{array}{l}\text { The child might focus more on the } \\
\text { entertainment of the materials; this will } \\
\text { cause laziness in studying. }\end{array}$ & Entertainment & Ent \\
\hline Par 13 & $\begin{array}{l}\text { I am sometimes being tempted to use } \\
\text { YouTube. }\end{array}$ & Entertainment & Ent \\
\hline \multirow{2}{*}{ Par 14} & \multirow{2}{*}{$\begin{array}{l}\text { If the materials are being overused and } \\
\text { being prioritized than to study. }\end{array}$} & Negligence & $\mathrm{Ngl}$ \\
\hline & & Limitless & Lml \\
\hline Par 15 & $\begin{array}{l}\text { It eats up my time because I play instead } \\
\text { of studying. }\end{array}$ & Engrossment & Egm \\
\hline Par 16 & $\begin{array}{l}\text { Due to being so much entertained. } \\
\text { Sometimes I am making my study time } \\
\text { shortened so that I can go back to my } \\
\text { gadgets already. }\end{array}$ & Engrossment & Egm \\
\hline
\end{tabular}




\begin{tabular}{|c|l|l|l|}
\hline & $\begin{array}{l}\text { One of the reasons for being materialistic } \\
\text { is the lack of contentment. So, you are } \\
\text { being more focused on the things your } \\
\text { parents might give to you than studying. } \\
\text { You give more attention to the things } \\
\text { because you don't what to be left out } \\
\text { with the trend. }\end{array}$ & Negligence & Ngl \\
\hline Par 18 & $\begin{array}{l}\text { Instead of doing activities/schoolworks, I } \\
\text { am tempted to watch k-drama or use FB. }\end{array}$ & Entertainment & Ent \\
\hline Par 19 & $\begin{array}{l}\text { As time goes by, my standards get higher } \\
\text { in all things I receive. }\end{array}$ & Dissatisfaction & Dsf \\
\hline Par 20 & $\begin{array}{l}\text { I'm having no time in studying because } \\
\text { of it. }\end{array}$ & Engrossment & Egm \\
\hline
\end{tabular}

Table 15. 1

Phase 2: Tallying of Negative Impacts of Materialism on Motivation in Learning

\begin{tabular}{|c|c|}
\hline Negative Impacts on Motivation & N \\
\hline Ngl & 7 \\
\hline Ent & 3 \\
\hline Egm & 5 \\
\hline Agt & 2 \\
\hline Anx & 1 \\
\hline Lml & 2 \\
\hline Dsf & 1 \\
\hline
\end{tabular}




\section{Table 15. 2}

Phase 3: Recurrent Themes

\begin{tabular}{|l|l|}
\hline \multicolumn{1}{|c|}{ Categories } & \multicolumn{1}{c|}{ Sub-categories } \\
\hline Discouraged by Temptation & $\begin{array}{l}\text { Negligence (DT-Ngl) } \\
\text { Entertainment (DT-Ent) }\end{array}$ \\
\hline Discouraged by Time Constraint & Engrossment (DTC-Egm) \\
\hline Discouraged by Bothersome & $\begin{array}{l}\text { Agitation (DB-Agt) } \\
\text { Anxiety (DB-Anx) }\end{array}$ \\
\hline Discouraged by Overuse & Limitless (DO-Lml) \\
\hline Discouraged by Dissatisfaction & Dissatisfaction (DD-Dsf) \\
\hline
\end{tabular}

Based on the presented data, five major negative impacts of materialism on motivation in learning were shown by the participants. The key-participants expressed that they were discouraged by temptation, overuse, time constraint, bothersome, and dissatisfaction. In majority, key-participants expressed that they were discouraged by temptation brought by materialism because of being entertained that would consequently lead them to neglect their education; a total of (10) responses on its sub-categories. Others also claimed that they were discouraged by time-constraint because of being engrossed to their materialistic provisions; a total of (5) responses on its sub-categories. Some key-participants expressed that they were discouraged by bothersome because of being agitated and anxious about materialism; a total of (3) responses on its subcategories. The key-respondents also claimed that they were discouraged because they overuse their materialistic possessions; (2) reponses on Limitless. A key-respondent 
expressed being discouraged because of dissatisfaction. Materialism demotivated the students because of having wrong priorities and diverted thinking.

A study conducted by (Iso, 2017) said that most of the OFW children have become so materialistic and spend their parent's money on gadgets and internet gaming from lack of guidance. The remittance is being wasted on self-absorption.

\section{Table 16}

Phase 1: Negative Impacts of Materialism on Class Participation

Question 13: How does materialism cause adverse effects on your class participation?

\begin{tabular}{|c|l|c|c|}
\hline $\begin{array}{c}\text { Key- } \\
\text { respondents }\end{array}$ & \multicolumn{1}{|c|}{ Retrieved Data } & Preliminary Codes & Codes \\
\hline Par 1 & $\begin{array}{l}\text { I use my time on unnecessary things } \\
\text { such as cell phone. }\end{array}$ & Unfocused & Unf \\
\hline Par 2 & $\begin{array}{l}\text { Like playing games on my cell } \\
\text { phone, I use my cell phone more than } \\
\text { taking down notes. }\end{array}$ & Electronic device & EDv \\
\hline Par 3 & $\begin{array}{l}\text { It causes bad manners. If we have } \\
\text { new things at our home, we can } \\
\text { become impatient and rude towards } \\
\text { our classmates and teachers. }\end{array}$ & Discourteous & Dcr \\
\hline Par 4 & $\begin{array}{l}\text { It can affect my participation } \\
\text { negatively when I'm too distracted by } \\
\text { the reward and not focused on the } \\
\text { process of how I'm going to achieve } \\
\text { that reward. }\end{array}$ & Reward & Rwd \\
\hline
\end{tabular}




\begin{tabular}{|c|c|c|c|}
\hline Par 5 & $\begin{array}{l}\text { It negatively affects my class } \\
\text { participation because sometimes it } \\
\text { reminds me about their situation, if } \\
\text { they are just okay working there, if } \\
\text { they eat at the right time, if they are } \\
\text { being abused by their employer. } \\
\text { When I think about those, I feel } \\
\text { weak. }\end{array}$ & Parental & Par \\
\hline Par 6 & $\begin{array}{l}\text { I am often being entertained by the } \\
\text { parental materialism and sometimes I } \\
\text { don't listen anymore or being sleep } \\
\text { deprived because of gadgets. }\end{array}$ & Unfocused & Unf \\
\hline Par 7 & $\begin{array}{l}\text { Sometimes I lose my motivation to } \\
\text { participate when I'm prioritizing } \\
\text { other things such as using my phone, } \\
\text { which causes me not to participate. }\end{array}$ & Electronic Devices & EDv \\
\hline Par 8 & $\begin{array}{l}\text { I rarely speak in class thanks to } \\
\text { isolating myself in my room because } \\
\text { I'm only focused on virtual } \\
\text { socializing and I don't intend to } \\
\text { socialize through verbal. }\end{array}$ & Unsociability & Uns \\
\hline Par 9 & I spend my money in other things. & Financial & Fnc \\
\hline Par 10 & $\begin{array}{l}\text { Sometimes I use my cell phone } \\
\text { during classes before. }\end{array}$ & Electronic Device & EDv \\
\hline Par 11 & $\begin{array}{l}\text { For example, my art materials, I'll } \\
\text { just draw and not participate } \\
\text { anymore. And then will just ignore } \\
\text { the class. }\end{array}$ & Unfocused & Unf \\
\hline \multirow{2}{*}{ Par 12} & \multirow{2}{*}{$\begin{array}{l}\text { The child can focus on the material } \\
\text { things. It can cause isolation and a } \\
\text { hindrance to become sociable. }\end{array}$} & Unfocused & Unf \\
\hline & & Unsociability & Uns \\
\hline Par 13 & $\begin{array}{l}\text { Sometimes I forget to read my books } \\
\text { because of using cell phone. }\end{array}$ & Electronic Device & EDv \\
\hline
\end{tabular}




\begin{tabular}{|c|l|c|c|}
\hline Par 14 & $\begin{array}{l}\text { Sometimes you'll just don't } \\
\text { understand the other things clearly } \\
\text { because you prioritize material } \\
\text { provisions. }\end{array}$ & Unfocused & Unf \\
\hline Par 15 & $\begin{array}{l}\text { It makes me distracted sometimes } \\
\text { because I think about what I will be } \\
\text { doing with that particular thing. }\end{array}$ & Unfocused \\
\hline Par 16 & $\begin{array}{l}\text { Distractions. Because when you have } \\
\text { all the resources with you there's a } \\
\text { tendency that you will be out of focus }\end{array}$ & Unfocused & Unf \\
\hline Par 17 & $\begin{array}{l}\text { Loss of focus in studying and } \\
\text { participating in class because of the } \\
\text { materials that you receive from OFW } \\
\text { parents. }\end{array}$ & Unfocused \\
\hline Par 18 & $\begin{array}{l}\text { If I'm not in the mood, I'm tempted } \\
\text { to use my cell phone or to give } \\
\text { attention to other things. }\end{array}$ & $\begin{array}{l}\text { Unfocused } \\
\text { I lose motivation when they give me } \\
\text { things or clothes, I don't like despite } \\
\text { of having high grades. }\end{array}$ & Unf \\
\hline Par 20 & $\begin{array}{l}\text { I play games during classes. } \\
\text { Pantentment }\end{array}$ & EDs \\
\hline
\end{tabular}

Table 16. 1

Phase 2: Tallying of Negative Impacts of Materialism on Class Participation

\begin{tabular}{|c|c|}
\hline Negative Impacts on Participation & $\mathrm{N}$ \\
\hline Unf & 10 \\
\hline EDv & 5 \\
\hline Rwd & 1 \\
\hline Fnc & 1 \\
\hline Uns & 2 \\
\hline Dcr & 1 \\
\hline Dsc & 1 \\
\hline
\end{tabular}




\section{Table 16. 2}

Phase 3: Recurrent Themes

\begin{tabular}{|l|l|}
\hline \multicolumn{1}{|c|}{ Categories } & \multicolumn{1}{c|}{ Sub-categories } \\
\hline Effect of Diversion & $\begin{array}{l}\text { Unfocused (ED-Unf) } \\
\text { Electronic Device (ED-EDv) } \\
\text { Reward (ED-Rwd) } \\
\text { Financial (ED-Fnc) }\end{array}$ \\
\hline Effect of Misdemeanor & $\begin{array}{l}\text { Unsociability (EM-Uns) } \\
\text { Discourteous (EM-Dcr) }\end{array}$ \\
\hline Effect of Regression & Discontentment (ER-Dsc) \\
\hline
\end{tabular}

Based on the presented data, three major negative impacts of materialism on class participation were shown by the participants. Key-participants expressed that materialism effectuates diversion, misdemeanor, and regression. In majority, key-participants expressed that materialism diverted their attention toward their materialistic possessions or about the reward they would get; (10) responses on Unfocused, (5) responses on Electronic Device, (1) response on Reward, and (1) response on Financial. Keyparticipants also claimed that materialism effectuated misdemeanor inside the class; (2) responses on Unsociability and (1) response on Discourteous. A key-respondent expressed being demotivated to take part because of dissatisfaction. The students' class participation were degraded by materialism because of being unfocused and having bad behaviors. 
A study conducted by (Iso, 2017) said that most of the OFW children have become so materialistic and spend their parent's money on gadgets and internet gaming from lack of guidance. The remittance is being wasted on self-absorption. (Mutie, 2015) claims that when parents superfluously provide their children with material things, the discipline of children may erode. 


\section{Summary, Findings, Conclusions, and Recommendations}

This section provided the summary of the research work undertaken and its findings, and discussed the conclusions based on the study findings and limitations. In addition, the recommendations made as an outgrowth of this study was presented.

\section{Summary}

This phenomenological study was focused on investigating the impacts of materialism on the academic behavior of students due to parental overseas employment. It was conducted in order to determine the positive and negative academic behavioral impacts of materialism towards the students. There were 20 students in Virgen Milagrosa University Foundation Special Science High School of the school year 2019-2020 who became the respondents of the study.

The research designed and utilized an unstructured interview. Frequency and percentage distribution were used in presenting the demographic profile of the respondents. Moreover, thematic analysis and tallying assessed the dominant indicators and factors of key-respondents' answers.

\section{Findings}

Considering the data gathered and the objectives of this study based on the statement of the problem, this study came with the following summarized findings based on themes:

1. Profile of the Respondents

a. Gender 
From the data gathered, 11 were females and 9 were males. Majority of the students who participated the research were females.

b. Age

The 12 participants were aged 15 years old while 8 participants were aged 14 years old.

c. Duration of their Overseas Employed Parents Abroad

There were 8 participants who responded that their parents were working abroad for 7 years and above. 6 participants responded being 11 months and under. There were 4 participants who responded 1-2 years and 2 participants on 3-4 years.

2. Perceptions of the Students about the Concept of Parental Materialism Majority of the key-participants precepted satisfaction; 7 responses. Next to this were the perception of neutral perception with 5 responses, and perception of limitation also with 5 responses. Followed by perception of disadvantage with 4 responses, then perception of coping mechanism with 3 responses.

3. Leading Materials Received by the Students

The leading materials received by the key-respondents were categorized. The top three materials were apparel with 18 responses, electronic devices with 16 responses, and financial assistance with 9 responses. The lesser three materials 
were food with 8 responses, personal things with 4 responses, and educational resources with 3 responses.

4. Positive Impacts of Materialism

a. Grades

Key-participants showed positive effects on their grades through having good incentive with 18 responses and well-being with 5 responses.

b. Educational resources

In majority, 14 responses of the key-participants showed that they purposefully use their materialistic provisions to help on their education. 4 responses of the key-participants expressed that their parents assure their educational resources. While 3 responses expressed that they attain educational resources by requesting their necessities to their parents.

c. Self-esteem

The key-participants expressed that materialism helps in boosting their self-esteem by conviction on their selves - 11 responses, assertiveness on what they do- 6 responses, and conformity to the society and peer groups - 5 responses.

d. Motivation in learning

The key-participants expressed that materialism motivates them to study well by extraneous reward, sense of reimbursement to their parents, and 
privilege. Each of these categories gained the same number of responses which was 7.

e. Class participation

The key-participants expressed that materialism helps improve their class participation because it acts as an advantage -13 responses and inducement to them- 12 responses.

5. Negative Impacts of Materialism

a. Grades

In majority, 11 responses of the key-participants expressed that materialism caused deflection. Then 4 responses on disturbance, 2 responses on demotivation, and 1 response on insufficiency.

b. Educational resources

The key-participants expressed that they were affected by misusage caused by being out of focus - 6 responses, exploitation among fellow students -3 responses, carelessness in handling things - 2 responses, immoderation or superfluous ma terials -2 responses, dependence on the provision -2 responses, dissatisfaction -1 responses, reticence on parents, and difficulty or inconvenience- 1 response.

c. Self-esteem

Key-participants expressed that they were driven by egotism- 11 responses, guilt -8 responses, self-negligence -4 responses, and poor socialization - 4 responses, because of materialism. 
d. Motivation in learning

In majority, 10 responses of the key-participants expressed that they were discouraged by temptation brought by materialism. Moreover, 5 responses stated that they were also discouraged by overuse of materials especially gadgets, 3 responses on time constraint, 2 responses on bothersome, and 1 response on dissatisfaction.

e. Class participation

Key-participants expressed that materialism effectuates diversion from the class - 17 responses, misdemeanor - 3 responses, and regression because of discontentment- 1 response.

\section{Conclusions}

Based on the findings of the study and the specific research questions, the researchers constructed the following conclusions comprehensively.

1. The profiles of the respondents gave additional information in the phenomena.

a. The students were aged 14 to 15 years old and on their adolescence period.

b. More female students opted to partake than male students.

c. Majority of the students has experienced long-term separations from their overseas employed parents.

2. The students understand that parental materialism from their overseas employed parents has purposeful advantages and aimless disadvantages. 
3. The academic behavior of the students was positively influenced by materialism due to parental overseas employment.

a. Materialism positively affected the grades of the students by effectuating good impacts on their incentive and well-being.

b. The students used the advantage of materialism to acquire educational resources.

c. Materialism swayed the students' thoughts in boosting their self-esteem.

d. Materialism drived the students' motivation in learning by rewards, along with parental inspiration and privilege.

e. The students used materialism as advantage and inducement in class participation.

4. The academic behavior of the students was negatively influenced by materialism due to parental overseas employment.

a. The students gave more priority to materialism - especially electronic devices, than to studying. Materialism have negative effects on their attitudes and behaviors.

b. Educational resources became superfluous and recreational. Materialism also negatively affected the students' satisfaction levels and conducts.

c. Materialism caused deprivation of the students' social life and personal aspect of their selves.

d. The students were demotivated by means of the sidetracks and dissatisfaction caused by materialism. 
e. The students were diverted from the class and are hindered to participate because of materialism. Materialism caused misconducts of the students among other people, as well as discontentment.

\section{Recommendations}

With thorough and in-depth conclusions of the study, recommendations were made for the different sectors, such as the school, parents, other family members, and students. These recommendations were as follows.

1. The school and teachers should have additional techniques on how to improve the academic performances of the students. They could also guide their students to be more responsible in school.

2. Parents should guide their children about proper self-control and limitations, but there must be also a strong relationship between them.

3. Other family members could decide to be the bridge for the overseas employed parents and the students, for better understanding and monitoring of their current condition.

4. Students are advised to appreciate their parents' love for them. They should also focus more on their studies than their materialistic provisions.

The following recommendations were also formulated for revalidation and expansion of future researches relevant to this study:

1. Include whether only their mother, father, or both of their parents are working abroad and indicate their socio-economic status. 
2. Future researchers might give emphasis to the effect of materialism on parentchild relationship.

3. Future researches relevant to this study might focus more on the coping mechanisms of the students with regards to the negative academic behavioral impacts of materialism.

4. Further researches might involve statements from the overseas employed parents.

5. Further researches might correspondingly be done by the influence of the emotional needs of the students. 
References

Alegria, E.J., Rivera, K.L., Bulan, J.M., \& Paclarin, A.M. (2018). Isolated souls: Exploring the effects of having OFW parents to the children left behind. Koronadal National Comprehensive High School-Senior High School, Koronadal City, South Cotabato, Philippines. www.academia.edu/37182167/ISOLATED_SOULS_EXPLORING_THE_EFFE CTS_OF_HAVING_OFW_PARENTS_TO_THE_CHILDREN_LEFT_BEHIND

Arguillas, M.J., \& William,s L. (2010). The impact of parents' overseas employment on educational outcomes of Filipino children. International Migration Review, 44(2), 300-319. https://doi.org/10.1111/j.1747-7379.2010.00807.x

Atienza, C., Kapunan, K., Noe, C., \& Panlilio, R. (2012, August 27). The experiences of adolescent children with parents as overseas Filipino workers. https://qualire2012a52.wordpress.com/2012/08/27/the-experiences-of-adolescentchildren-with-parents-as-overseas-filipino-workers/

Baraceros, E.L. (2016). Practical research 1. Manila, PH: Rex Book Store, Inc.

Bernardo, A.B., Mansukhanib, R.T., \& Daganzoa, M.A. (2018). Associations between materialism, gratitude, and well-being in children of overseas Filipino workers. Europe's Journal of Psychology, 14(3), 581-598.

https://doi.org/10.5964/ejop.v14i3.1555 
Botezat, A., \& Pfeiffer, F. (2014). The impact of parents migration on the well-being of children left behind: Initial evidence from Romania. ZEW - Centre for European Economic Research. https://doi.org/10.2139/ssrn.2432946

Elmore, T. (2013, July 3). How materialism can hinder maturity in students. https://growingleaders.com/blog/how-materialism-can-hinder-maturity-instudents/

Elodie, G., Shrum, L. J., \& Lowrey, T. M. (2018). Coping with loneliness through materialism: Strategies matter for adolescent development of unethical behaviors. Journal of Business Ethics, 152 (1), 103-122. https://doi.org/10.2139/ssrn.2866806

Espiritu, B.X. (2015, June 2). How materialism flourishes among the 'always-on' generation. http://www.mulatpinoy.ph/2015/06/02/materialism-flourishes-amongalways-on-generation/

De Mey, L., \& Smith, D. (2013). Advanced research methods. London, UK: SAGE Publishing.

Foley, B. (2018, June 4). The advantages \& disadvantages of quota sampling. https://www.surveygizmo.com/resources/blog/quota-sampling/

Iso G.M. (2017). OFWs and the children left behind. https://philippineone.com/ofws-andthe-children-left-behind/ 
King R.B., \& Datu J.A. (2017). Materialism does not pay: Materialistic students have lower motivation, engagement, and achievement. Contemporary Educational Psychology, 49, 289-301. https://doi.org/10.1016/j.cedpsych.2017.03.003

Kohli, S. (2015, March 6). Parents are unconsciously setting their kids up to be materialists with fragile egos. https://qz.com/356880/parents-are-unconsciouslysetting-their-kids-up-to-be-materialists-with-fragile-egos/amp/

Lu Y. (2014). Parental migration and education of left-behind children: A comparison of two settings. Journal of Marriage and Family, 76(5), 1082-1098. https://doi.org/10.1111/jomf.12139

Moshahid M., \& Vadakkayil S.T. (2016). Influence of parental attention on the academic achievement of secondary school students of expatriate parents. http://ndpublisher.in/admin/issues/LCV7N3i.pdf

Mutie, J. (2015). Effects of emotionally absent parents on the behavior of adolescents in selected secondary schools in Machakos County, Kenya. Kenyatta University, Nairobi, Kenya. http://ir-library.ku.ac.ke/handle/123456789/14414

Richins M.L., \& Chaplin L.N. (2015). Material parenting: How the use of goods in parenting fosters materialism in the next generation. Journal of Consumer Research, 41(6), 1333-1357. https://doi.org/10.1086/680087 
Tian Y., \& Lu D. (2015). The experimental research on the influence of materialism and the emotion of awe on life satisfaction and products preference. Open Journal of Social Sciences, 3, 138-145. https://doi.org/10.4236/jss.2015.310020

Philippine Statistics Authority. (2019, April 30). Total number of OFWs estimated at 2.3 million: Results from the 2018 Survey on Overseas Filipinos (Reference No. 2019-066). https://psa.gov.ph/statistics/survey/labor-and-employment/surveyoverseas-filipinos

Wang R., Liu H., Jiang J., \& Song Y. (2016). Will materialism lead to happiness? A longitudinal analysis of the mediating role of psychological needs satisfaction. Personality and Individual Differences, 105, 312-317. https://doi.org/10.1016/j.paid.2016.10.014 


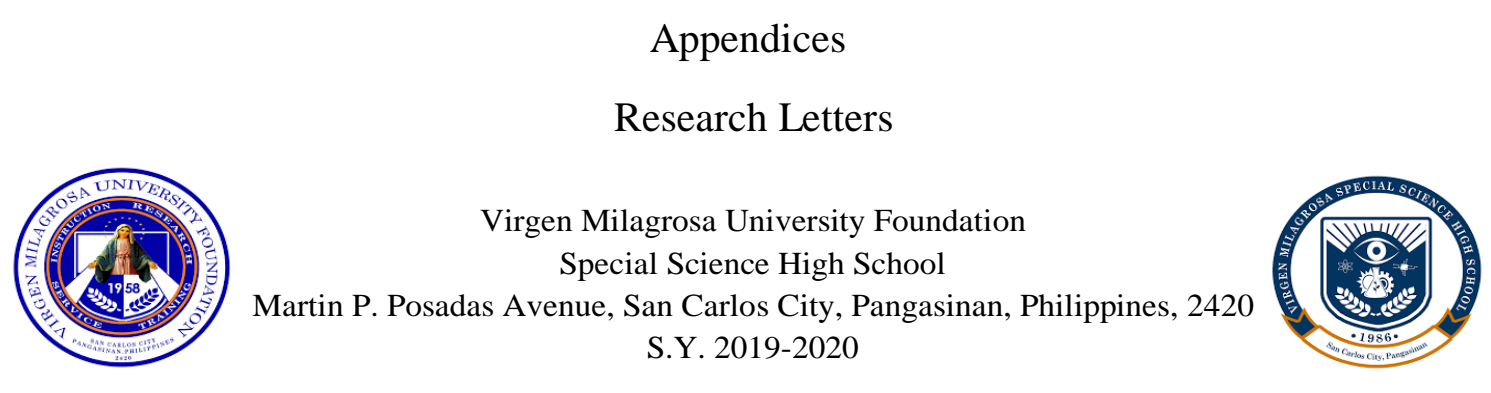

\section{Letter of Approval}

March 10, 2020

RIA S. CAGUIOA, MSc.

Principal

VMUF-Special Science High School

\section{Dear Ma'am:}

Good day!

We, the undersigned, are currently conducting a research study entitled "The Impacts of Materialism on the Academic Behavior of Students due to Parental Overseas Employment", as deemed required for our subject Practical Research 1.

In this regard, we are humbly asking your good office for permission to interview 20 Grade 9 students of Virgen Milagrosa University Foundation Special Science High School. We believe that their insights and experiences regarding our research will be significant upon ensuring a sound and reliable result.

Furthermore, we assure you that the identity of the respondents and the data we will be gathering shall be treated with absolute discretion and confidentiality and will be used for academic purposes only.

We hope for your positive response on this humble request.

Sincerely Yours,

Researchers:

Rei Joshua R. Amante

Rashela C. Ballesteros

John Kenneth S. Lopez

Yiana Maristela L. Mislang

Ashley Nicole M. Rosario

Junalyn C. Seguin

Noted by:

BOBBY B. DELA CRUZ

Research Adviser

Approved by:

RIA S. CAGUIOA, MSc.

Principal 


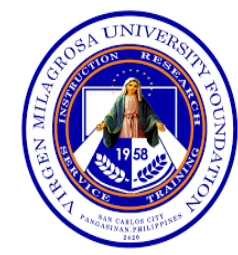

\author{
Virgen Milagrosa University Foundation \\ Special Science High School \\ Martin P. Posadas Avenue, San Carlos City, Pangasinan, Philippines, 2420 \\ S.Y. 2019-2020
}

\title{
Letter of Consent
}

\section{Dear Respondent:}

We, the undersigned researchers, are currently conducting a research study entitled "The Impacts of Materialism on the Academic Behavior of Students due to Parental Overseas Employment", as deemed required for our subject Practical Research 1.

In connection with this, we are humbly asking you to partake and help us in providing the necessary data for this study. We believe that your insights and experiences regarding our study will be of great help. Rest assured that any information will be treated with utmost confidentiality. Your assistance and support will be appreciated in this particular research endeavor.

Thank you for sharing your time with us.

\section{Sincerely Yours,}

\section{Researchers:}

Rei Joshua R. Amante

Rashela C. Ballesteros

John Kenneth S. Lopez

Yiana Maristela L. Mislang

Ashley Nicole M. Rosario

Junalyn C. Seguin

SIGNATURE OVER PRINTED NAME 


\author{
Qualifications of the Key-respondents \\ Virgen Milagrosa University Foundation \\ Special Science High School \\ Martin P. Posadas Avenue, San Carlos City, Pangasinan, Philippines, 2420 \\ S.Y. 2019-2020

\section{The Impacts of Materialism on the Academic Behavior of Students due to Parental Overseas Employment}

Qualifications of the Key-respondents:

1. The respondent must be enrolled at Virgen Milagrosa University Foundation Special Science High School for the school year 2019-2020.

2. The respondent must be a Grade 9 Student of Virgen Milagrosa University Foundation Special Science High School.

3. The respondent must be one of the five (5) respondents from the four (4) sections of Acacia, Cedar, Molave, and Narra.

4. The respondent must have (an) Overseas Filipino Worker (OFW) Parent/s.

5. The respondent has been experiencing parental materialism.

6. The respondent's academic behavior is influenced by parental materialism.

7. The respondent is willing to partake in the research interview. 


\author{
Data Gathering Tools \\ Virgen Milagrosa University Foundation \\ Special Science High School \\ Martin P. Posadas Avenue, San Carlos City, Pangasinan, Philippines, 2420 \\ S.Y. 2019-2020 \\ The Impacts of Materialism on the Academic Behavior of Students due to Parental \\ Overseas Employment

\section{QUESTIONNAIRE}

Directions: Kindly respond to the following questions by filling out and placing a check mark in the answer box that corresponds to your answer.

\title{
PART I: RESPONDENT'S PROFILE
}

Name: (optional)

Age:

$\square \quad 13$ years old \& below

$\square \quad 14$ years old

$\square \quad 15$ years old

$\square \quad 16$ years old

$\square \quad 17$ years old \& above

Gender:

$\square \quad$ Male

$\square \quad$ Female

Select the duration of your OFW parents abroad:

$0-11$ months

$\square \quad 1-2$ years

$\square \quad 3-4$ years 
$\square \quad 5-6$ years

7 years above

\section{PART II: INTERVIEW GUIDE QUESTIONS}

1. What can you say about parental materialism?

2. What are the three leading materials that you receive from your parents?

3. How does materialism compensate for your parent's absence?

4. How does parental materialism impact your grades positively?

5. How does materialism help you to gain more educational resources?

6. How can materialism positively affect your self-esteem?

7. How does materialism drive your motivation to study well?

8. How does materialism positively influence your participation in the class?

9. How does parental materialism impact your grades negatively?

10. What do you think are the bad effects of materialism on your educational resources?

11. Give some negative impacts of materialism on your self-esteem.

12. How does materialism distract you from studying?

13. How does materialism cause adverse effects on your class participation? 


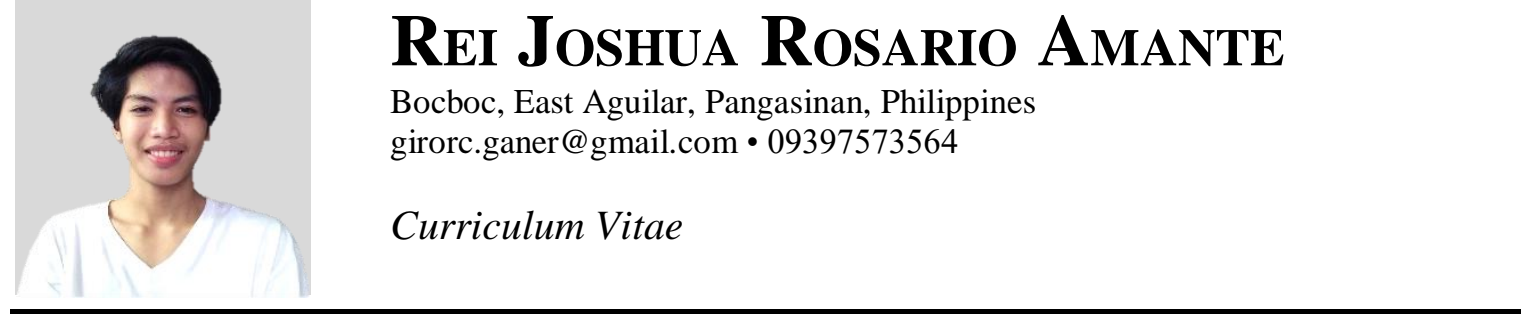

\section{PERSONAL INFORMATion}

Age: $\quad 16$

Date of Birth: $\quad$ April 16, 2004

Place of Birth: $\quad$ San Carlos City, Pangasinan

Civil Status: $\quad$ Single

\section{EDUCATIONAL BACKGROUND}

Secondary: Virgen Milagrosa University Foundation - Special Science HS

M. P. Posadas Ave., San Carlos City, Pangasinan

2017-Present

Primary: Virgen Milagrosa University Foundation Child Learning Center

M. P. Posadas Ave., San Carlos City, Pangasinan

2011-2017

Preschool: Saint Charles Academy

Palaris St., San Carlos City, Pangasinan

2008-2011 


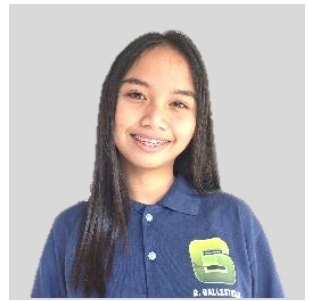

Rashela Cariño Ballesteros

Ano, San Carlos City, Pangasinan, Philippines

rashelacarinoballesteros@gmail.com•09959600511

Curriculum Vitae

\section{PERSONAL INFORMATION}

Age: $\quad 15$

Date of Birth: $\quad$ April 16, 2005

Place of Birth: $\quad$ San Carlos City, Pangasinan

Civil Status: $\quad$ Single

\section{EDUCATIONAL BACKGROUND}

Secondary: Virgen Milagrosa University Foundation - Special Science HS

M. P. Posadas Ave., San Carlos City, Pangasinan

2017-Present

Primary: Ano Elementary School

Brgy. Ano, San Carlos City, Pangasinan

2011-2017

Preschool: St. John's Cathedral School

Zamora St., Dagupan City, Pangasinan

2009-2011

Day Care Center

Brgy. Pantal, Dagupan City, Pangasinan

2008-2009 


JOHN KENNETH SEMANA LOPEZ
Tandoc, San Carlos City, Pangasinan, Philippines
johnkenneth_lopez@yahoo.com $\bullet 09773716530$

\section{PERSONAL INFORMATION}

Age: $\quad 14$

Date of Birth: $\quad$ October 4, 2005

Place of Birth: $\quad$ San Carlos City, Pangasinan

Civil Status: $\quad$ Single

\section{EDUCATIONAL BACKGROUND}

Secondary: Virgen Milagrosa University Foundation - Special Science HS

M. P. Posadas Ave., San Carlos City, Pangasinan

2017-Present

Primary: Gospel of Christ School of San Carlos

M. P. Posadas Ave., San Carlos City, Pangasinan

2011-2017

Preschool: University of the East Caloocan

Samson Rd., Caloocan City, Kalakhang Maynila

2008-2011 


YIANA MARISTELA LINCOD MISLANG
$\begin{aligned} & \text { Ano, San Carlos City, Pangasinan, Philippines } \\ & \text { maristelamislang@gmail.com •09276547164 } \\ & \text { Curriculum Vitae }\end{aligned}$

\section{PERSONAL INFORMATION}

Age: $\quad 15$

Date of Birth: $\quad$ May 28, 2005

Place of Birth: $\quad$ San Carlos City, Pangasinan

Civil Status: $\quad$ Single

\section{EDUCATIONAL BACKGROUND}

Secondary: Virgen Milagrosa University Foundation - Special Science HS

M. P. Posadas Ave., San Carlos City, Pangasinan

2017-Present

Primary: Ano Elementary School

Brgy. Ano, San Carlos City, Pangasinan

2011-2017

Preschool: Ano Elementary School

Brgy. Ano, San Carlos City, Pangasinan

2010-2011 


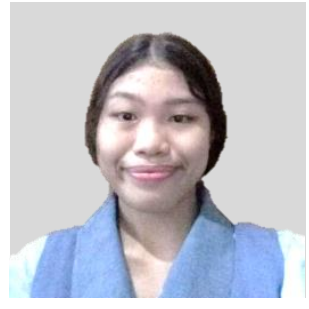

\section{Ashley Nicole Medenilla Rosario}

Balaya, San Carlos City, Pangasinan, Philippines

ashleynicole.rosario@yahoo.com•09729246440

Curriculum Vitae

\section{PERSONAL INFORMATion}

Age: $\quad 14$

Date of Birth: $\quad$ February 10, 2006

Place of Birth: $\quad$ San Carlos City, Pangasinan

Civil Status: $\quad$ Single

\section{EDUCATIONAL BACKGROUND}

Secondary: Virgen Milagrosa University Foundation - Special Science HS

M. P. Posadas Ave., San Carlos City, Pangasinan

2019-Present

Saint Mary's Academy

Brgy. Andres Bonifacio, Diffun, Quirino

2017-2019

Primary: Saint Mary's Academy

Brgy. Andres Bonifacio, Diffun, Quirino

2011-2017

Preschool: Amazing West Kiddie Learning Center

Brgy. Aurora West, Diffun, Quirino

2009-2011 


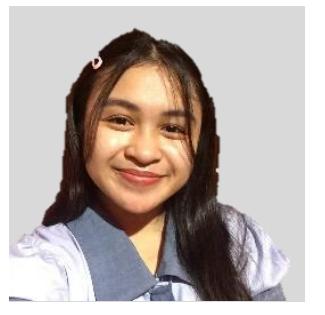

\section{Junalyn Caunceran Seguin}

Anambongan, Basista, Pangasinan, Philippines

junaseguin23@gmail.com•09156824534

Curriculum Vitae

\section{PERSONAL INFORMATION}

Age: $\quad 15$

Date of Birth: July 23, 2004

Place of Birth: $\quad$ San Carlos City, Pangasinan

Civil Status: $\quad$ Single

\section{EDUCATIONAL BACKGROUND}

Secondary: Virgen Milagrosa University Foundation - Special Science HS

M. P. Posadas Ave., San Carlos City, Pangasinan

2017-Present

Primary: $\quad$ Bancolita-Frias Family (BFF) Learning Academy

Brgy. Dumpay, Basista, Pangasinan

2011-2017

Preschool: Bancolita-Frias Family (BFF) Learning Academy

Brgy. Dumpay, Basista, Pangasinan

2008-2011 